\title{
Managing sustainability risks of bioenergy in four Nordic countries
}

\author{
Anders Chr. Hansen ${ }^{1}$, Nicholas Clarke ${ }^{2^{*}}$ (1) and Atle Wehn Hegnes ${ }^{2}$
}

\begin{abstract}
Background: Bioenergy plays a key role in the transition to a sustainable economy in Europe, but its own sustainability is being questioned. We study the experiences of Sweden, Finland, Denmark and Norway, to find out whether the forest-based bioenergy chains developed in the four countries have led to unsustainable outcomes and how the countries manage the sustainability risks. Data were collected from a diversity of sources including interviews, statistical databases, the scientific literature, government planning documents and legislation.

Results: Sustainability risks of deforestation, degradation of forests, reduced carbon pools in forests, expensive biopower and heat, resource competition, and lack of acceptance at the local level are considered. The experience of the four countries shows that the sustainability risks can to a high degree be managed with voluntary measures without resorting to prescriptive measures. It is possible to add to the carbon pools of forests along with higher harvest volumes if the risks are well managed. There is, however, a marginal trade-off between harvest volume and carbon pools. Economic sustainability risks may be more challenging than ecological risks because the competitiveness order of renewable energy technologies has been reversed in the last decade. The risk of resource competition harming other sectors in the economy was found to be small and manageable but requires continuous monitoring. Local communities acting as bioenergy communities have been agents of change behind the most expansive bioenergy chains. A fear of non-local actors reaping the economic gains involved in bioenergy chains was found to be one of the risks to the trust and acceptance necessary for local communities to act as bioenergy communities.

Conclusions: The Nordic experience shows that it has been possible to manage the sustainability risks examined in this paper to an extent avoiding unsustainable outcomes. Sustainability risks have been managed by developing an institutional framework involving laws, regulations, standards and community commitments. Particularly on the local level, bioenergy chains should be developed with stakeholder involvement in development and use, in order to safeguard the legitimacy of bioenergy development and reconcile tensions between the global quest for a climate neutral economy and the local quest for an economically viable community.
\end{abstract}

Keywords: Bioenergy, Sustainability, Risk assessment, Risk management, Nordic countries

\section{Introduction and background}

The four Nordic countries Sweden, Finland, Norway and Denmark share goals of transforming their economies to low carbon dioxide emission economies. Compared

*Correspondence: nicholas.clarke@nibio.no

${ }^{2}$ Norwegian Institute of Bioeconomy Research, P.O. Box 115, N-1431 Ås, Norway

Full list of author information is available at the end of the article to 1990 greenhouse gas emissions, Sweden plans to emit maximum $15 \%$ by 2045 [1], Norway $5-10 \%$ by 2050 [2, 3], Finland $15 \%$ by 2050 [4-6], and Denmark $5-20 \%$ by 2050 [7]. The countries plan to reach a climate neutral economy by compensating for the remaining emissions by extracting a similar amount of $\mathrm{CO}_{2}$ from the atmosphere and storing it in forests, applying carbon capture and storage technologies, or paying for reduction of $\mathrm{CO}_{2}$ emissions in other countries. Norway plans to reach original author(s) and the source, provide a link to the Creative Commons licence, and indicate if changes were made. The images or other third party material in this article are included in the article's Creative Commons licence, unless indicated otherwise in a credit line to the material. If material is not included in the article's Creative Commons licence and your intended use is not permitted by statutory regulation or exceeds the permitted use, you will need to obtain permission directly from the copyright holder. To view a copy of this licence, visit http://creativecommons.org/licenses/by/4.0/. The Creative Commons Public Domain Dedication waiver (http://creativeco mmons.org/publicdomain/zero/1.0/) applies to the data made available in this article, unless otherwise stated in a credit line to the data. 

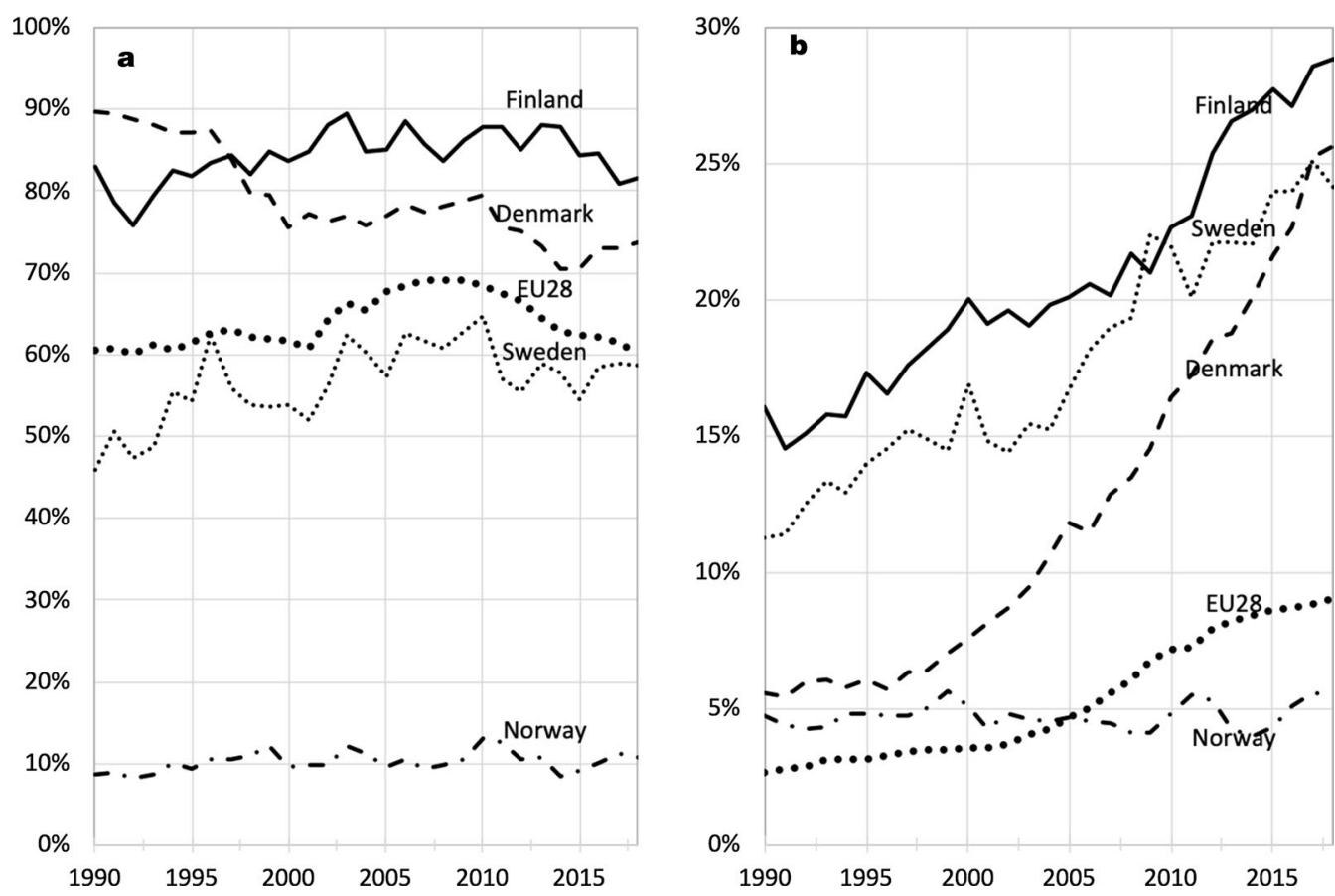

Fig. 1 Bioenergy as a percentage of $\mathbf{a}$ energy from renewable sources and $\mathbf{b}$ gross inland energy consumption in Sweden, Finland, Norway, Denmark, and the EU 1990-2018. Source: authors' calculations based on EUROSTAT data [115]

climate neutrality by 2030 [2, 3], Finland by 2035 [4-6], Sweden by 2045 [1] and Denmark by 2050 [7]. Forests and bioenergy play important roles in these transition strategies, in particular until electricity storage technologies become sufficiently developed.

Over three decades, large parts of the fossil energy economy of three of the countries have been transformed to bioenergy. Bioenergy provided by 2016 two thirds of the renewable energy in the EU (Fig. 1) and has been projected to develop further in the 2020s. The development of bioenergy measured by its share in gross inland energy consumption is shown for the four Nordic countries and the EU in Fig. 1.

Finland and Sweden have 31\% of the total EU forest area [8]. The two countries have since around 1990 developed strong forest-based energy supply chains. Denmark has developed bioenergy supply chains to a similar degree but has a small forest area. Norway has a large forest area but has not developed bioenergy. Its exceptionally rich hydropower resources are more competitive (Fig. 1). The production and use of bioenergy per capita are high in Sweden and Finland, whereas it is considerably lower in Denmark. In Norway it is even lower (Fig. 2).

To understand the risks associated with the development of bioenergy, we tried to find out which bioenergy chains are expanding. To that end, we separated the flows of biomass energy carriers in six separate bioenergy chains identified by their type of energy conversion (Fig. 2). They are quantified by the energy consumption at the conversion stage.

The bioenergy chains identified include: (i) the conversion of biomass waste from own processes in the wood, pulp and paper industry, (ii) the conversion of wood biomass and municipal waste to power and district heating ("bioenergy-to-grid"), (iii) the similar conversion of waste streams in forest industries to steam and power ("industry bioenergy-to-grid", (iv) the production of liquid and gaseous biofuels, (v) bioenergy in other industries, and (vi) the traditional use of firewood in households ("residential and services").

The most expansive of these bioenergy supply chains in 1990-2015 in all four countries has been the bioenergy-to-grid chain, whereas biofuel chains have been rather small and sourced primarily from imported oils and food or feed crops. District heating is reaching a saturation point in the four countries and the bioenergy-to-grid chain is not likely to be expansive in the future [9]. Biofuels are candidates for fuelling long distance transport and the sourcing of the biofuel supply chain is redirected by EU legislation from food and feed crops towards lignocellulosic biomass such as wood and agriculture residues. Some of the pulpwood waste flows that are today converted to steam and heat for 

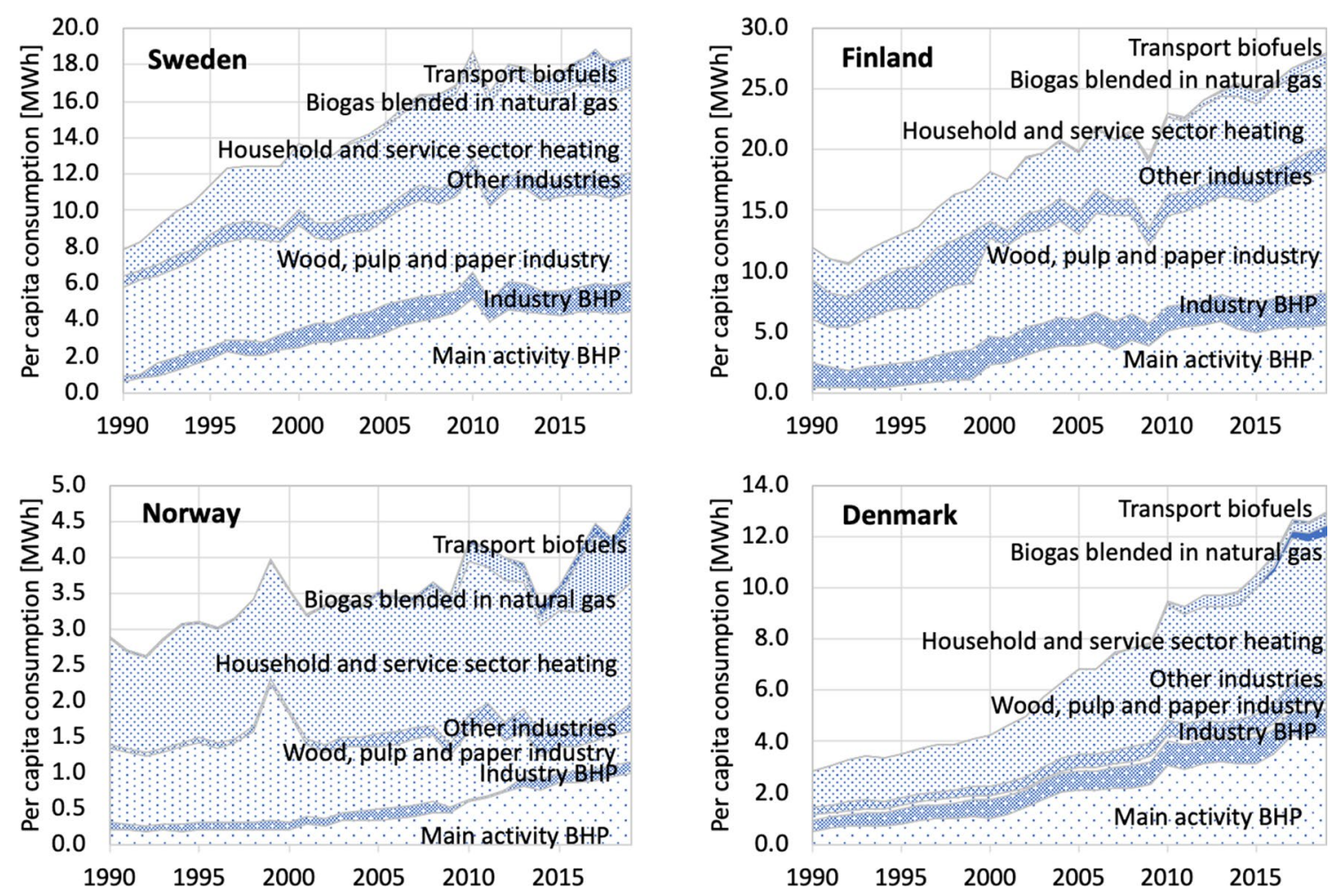

Fig. 2 Bioenergy chains in Sweden, Finland, Norway and Denmark, 1990-2015. MWh per capita. Bioenergy value chains are defined by consumption (Lower Heating Value) of biofuels in the conversion link. Note the different scales. BHP= biomass to heat and power. Source: authors' calculations based on EUROSTAT data [116]

processes in the pulp and paper industry may even be converted to biofuels instead [10].

The expansion of bioenergy-to-grid value chains has superseded fossil fuel and peat-based heat and power generation, but they also compete with electrical heat pumps. These are very common in Norway where electricity has been cheap. The low penetration of bioenergy-to-grid chains in Norway is also related to the fact that only a small fraction of the total heated floor area of buildings is designed with waterborne heating. This limits the potential for district heating and thus the potential for bioenergy-to-grid chains becomes saturated at a lower level. The share of dwellings with waterborne heating rose from $8 \%$ (of which $1 \%$-point district heating) in 2001 to $15 \%$ (of which 4\%-points district heating) by 2012 [11]. In the other countries, the competitiveness of biomass-based district heating has been improved by biomass subsidies and higher electricity taxes [12-15].

These bioenergy pathways have been developed to mitigate climate change risks and must comply with principles of protecting environmental values of forests [16]. However, the sustainability of bioenergy development has itself been questioned [17-19]. We call the risks of inadvertently causing unsustainable outcomes while pursuing transitions to a sustainable economy "sustainability risks".

This paper aims at identifying and assessing risks and risk management related to bioenergy development, focussing largely on the local level, in the experience of the four Nordic countries. We do this largely by reviewing the scientific literature and other relevant documents, but also include results from interviews with relevant actors in northern Norway. The paper is not an exhaustive review, but instead literature is included up to a point where it adequately justifies the argument being made.

\section{Conceptual framework and methods}

\section{Key interdisciplinary concepts}

Bioenergy "pathways", "supply chains" or "chains" are the physical chains of energy carriers from biomass (as primary energy carrier) to fuels and converted to energy for final use. From an economic point of view, the energy carriers gain economic value in each link. Their market value increases with their usability. From a physical perspective, they lose energy, link by link, due to transport, storage and conversion. Bioenergy chains have been developed in the four countries 
to restructure parts of the energy sector to sustainable production and use of energy (Figs. 1 and 2).

Sustainability is an interdisciplinary concept and the study of sustainability risk requires an interdisciplinary palette of methods and approaches. The World Commission on Environment and Development (the Brundtland Commission) defined sustainable development as a development of society that "meets the needs of the present without compromising the ability of future generations to meet their own needs" and added that sustainable development "requires meeting the basic needs of all and extending to all the opportunity to fulfil their aspirations for a better life" ([20], paragraph 27).

The concept of sustainable development was explained in Agenda 21 and other UN documents as balanced progress in the social, economic and ecological dimensions, specifying reduction and avoidance of imbalances within and between the dimensions [21]. In particular, economic growth at the cost of regression in the ecological or social dimension is not sustainable development. Neither is progress in the ecological dimension due to economic recession such as during the financial crisis or the corona pandemic. Progress in the three dimensions is now specified in 15 of the 17 sustainable development goals and a fourth dimension, governance, has been added (goals 16 and 17 on conflict resolution and equal partnerships) [22].

The development of bioenergy chains replacing fossil energy chains in the four countries is intended to be part of a sustainable development of society. Sustainability risks are the risks of inadvertently causing retrogression in one or more dimensions, despite the intention of generating progress in all four dimensions. Backward steps in one or more of the four dimensions can result in imbalances in one or more dimensions.

"Risk" is commonly understood as negative or undesirable, but uncertain, outcomes of actions or scenarios pursuing desirable goals. Academic disciplines offer a variety of approaches to risk and uncertainty. Across quantitative disciplines, risks are quantified as the product of consequence and its probability. The implication of taking this "magnitude x likelihood" approach to quantitative risk assessment is that risks of catastrophic impact are not neglected or dismissed due to low probability. This is also the standard approach to quantitative risk assessment in science and technology.

The IPCC has developed an interdisciplinary approach to the assessment of magnitude as well as likelihood of consequences. The scientific confidence in the assessment of both factors depends on the available evidence and on the scientific agreement on methodology and theories underlying its interpretation [23].
Other academic disciplines such as sociology, psychology and anthropology are more concerned with qualitative changes and interpretation. They focus on the perceptions of risks and the role of risks as a profound characteristic of society. Beck describes society by the turn of the century as the "risk society", generating "manufactured uncertainties" [24, 25], which lead to risks that are global in scope, work across generations and are universal. They are individually uncontrollable, and their costs cannot be shared by insurance or similar arrangements. To various degrees, however, they are societally or collectively manageable.

Climate change risks are managed by mitigation measures such as developing and deploying bioenergy solutions. These may, however, entail risks of their own and may inadvertently cause unsustainable outcomes, despite their intended contributions to a sustainable economy. We call these risks "sustainability risks". They can be regarded as second order manufactured risks. They are man-made and collectively manageable.

Luhman distinguishes between risk and danger, where risk is the prospect of undesirable outcomes in technical terms, whereas danger is the broader fear of undesirable outcomes as perceived by citizens in general. The latter is closely related to the development of trust [26]. Renn and others recommend broadening the standard "magnitude x likelihood" approach to a risk governance approach including these aspects of risk in society [27].

Sustainability risks of bioenergy are not a new challenge to Europe. Before industrialisation, unsustainable use of forests led to deforestation of large areas of Europe [28]. Forest areas were cleared not only for agriculture and supply of wood as material, but also for bioenergy, e.g., for mining and the metal industry. The concept of sustainability was probably first introduced by the mining director von Carlowitz in 1713 [29]. In his guidance for wild tree cultivation ("Anweisung zur Wilden BaumZucht"), he warned against a failing wood supply due to overharvesting. He argued for letting the trees grow to maturity and for replanting new trees after harvesting, thus conserving the forest resource and production capacity.

In Denmark and even in parts of Norway, Sweden and Finland, unsustainable utilization before industrialisation led to deforestation $[28,30]$. The forest cover in Denmark was reduced to $2 \%$ by 1800 [31] However, through the twentieth century in particular large forest areas have recovered [32]. Thus, the four countries have ample experience with unmanaged as well as managed sustainability risks of forest-based bioenergy.

Today, the concept of sustainable forest management includes not only the supply of wood, but all ecosystem services provided by forests. Sustainable forest 
management can now be defined as "the stewardship and use of forests and forest lands in a way, and at a rate, that maintains their biodiversity, productivity, regeneration capacity, vitality and their potential to fulfil, now and in the future, relevant ecological, economic and social functions, at local, national, and global levels, and that does not cause damage to other ecosystems" [33].

"Ecosystem services" are the services from nature benefitting humans and their economy including abiotic elements such as the climate system. They include: (i) the services of materials and energy provision, (ii) regulation of the hydrological cycle, the carbon cycle, the nutrient cycles and other of the great cycles of nature and the economic use of these cycles, and (iii) cultural services such as recreation and cultural identity. Life supporting services on which the other services rest, such as photosynthesis, nutrient cycling and soil formation, are sometimes considered a separate group of ecosystem services and sometimes as underpinning all ecosystem services [34-38]. Generally, sustainability risks in the ecological dimension can be described as ecological imbalances caused by overconsumption (i.e. excessive use leading to depletion) of the ecosystem services provided by forests and other biomass production systems.

\section{Identification of sustainability risks to be assessed}

In this section, we identify key issues which will be treated in this paper, based on issues previously identified by others. Bioenergy sustainability risks identified by the IPCC include land-use change from forest to agriculture and other reductions of carbon pools, larger flows of nitrogen use and emissions of $\mathrm{N}_{2} \mathrm{O}$ and $\mathrm{NH}_{3}$, higher water demand, reduced biodiversity, and risks to food security (quantities and prices) [39]. In the future, new risks such as leaks from mineral storage of carbon from bioenergy with carbon capture and storage (BECCS) systems might arise as technologies mature and are implemented at larger scale. Lattimore et al. found six classes of environmental risks associated with forest-based bioenergy, i.e. risks to: (i) soils, (ii) hydrology and water quality, (iii) site productivity, (iv) forest biodiversity, (v) greenhouse gas balances, and (vi) global and supplychain impacts of bioenergy production [40]. The European Commission identified seven sustainability risks related to bioenergy, including deforestation and forest degradation, emissions from land use, land use change and forestry, upstream greenhouse gas emissions and air emissions from combustion. They also included two economic sustainability risks: diversion of wood from material use and inefficient bioenergy generation [41]. The European Commission also summarized sustainability risks of bioenergy in the consultations with the public prior to the revision of the renewable energy directive as: (i) biogenic $\mathrm{CO}_{2}$ emissions and supply chain emissions, (ii) adverse environmental impacts on biodiversity, soil and air quality, (iii) use in low-efficiency installations, and (iv) administrative burdens and related costs [42]. These sustainability risks related to bioenergy have been considered in the lawmaking process leading to the revised directive on energy from renewable sources [43]. They can be classified as ecological or economic sustainability risks. There may be important sustainability risks related to the development of the bioenergy chains with district heating that constitute the most expansive bioenergy chains in Sweden, Finland and Denmark in the period 1990-2015. If this entails significantly higher heating prices, inequality in consumption opportunities may be deepened, representing a risk of economic and social imbalances.

The bioenergy chains replacing fossil fuels in the four countries would not have been developed without government support. Market prices can be seen as signals of the effects on the economy of a transaction, but only so far as these effects are mediated through the partners of the transaction. Effects of fossil fuel combustion on urban air pollution and climate change and effects on technological knowledge of industrial experience with new solutions are not signalled by market prices unless governments intervene. These effects on the rest of society are called external effects. Energy markets left without management of the external effects lead to suboptimal development of renewable energy potentials, including bioenergy. Economic risks may, however, also arise if governments develop bioenergy beyond what is justified by these external effects. Excessive bioenergy production and use entails risks of economic imbalances in the form of higher costs than necessary for energy from renewable sources and of losses due to distortions of markets connected to the bioenergy chains.

The bioenergy chains involving district heating would not have developed without strong political support and acceptance from the local community. In all four countries, they are typically developed by networks of suppliers led by the municipality and its utilities. If these local projects lose public support, they face a governance sustainability risk. This could be a result of the ecological, economic and social risks materializing, but it could also be a result of governance issues such as inadequate local cooperation and conflict resolution or national authorities overriding local decisions.

Against this backdrop, we identify the following sustainability risks and group them in the dimensions of sustainable development, also giving the methodology we have used in this paper to discuss each risk (Table 1):

The assessment of these risks must necessarily use a variety of approaches and is therefore an interdisciplinary 
Table 1 Summary of the sustainability risks discussed in this paper and the methodology used

\begin{tabular}{ll}
\hline Sustainability risks & Approach/method \\
\hline Ecological sustainability risks & \\
$\begin{array}{l}\text { Deforestation, forest degradation and reduced wood supply } \\
\text { Risks to carbon stocks }\end{array}$ & Analysis of statistics from national statistics and reporting to the UNCFFF \\
$\begin{array}{l}\text { Other ecological sustainability risks, e.g. adverse impacts on biodiversity } \\
\text { and soil, water, and air quality }\end{array}$ & Analysis of statistics from national statistics and reporting to the UNCFFF \\
$\begin{array}{ll}\text { Economic sustainability risks } \\
\text { Excessivate governance measures }\end{array}$ & \\
$\begin{array}{l}\text { Excessive development of bioenergy rather than other renewable energy } \\
\text { technologies }\end{array}$ & Statistical analysis and review of the literature \\
$\begin{array}{l}\text { Social sustainability risks } \\
\text { Socially undesirable distribution between income groups and regions }\end{array}$ & Interviews, literature (see next sub-section for details) \\
$\begin{array}{l}\text { Governance sustainability risks } \\
\text { Community trust and acceptance }\end{array}$ & Interviews (see next sub-section for details) \\
\hline
\end{tabular}

challenge. The ecological, economic and social sustainability risks can be understood as risks of imbalances caused by overconsumption of ecosystem services of forests, innovation resources and consumption opportunities of specific groups of the population. They are often formulated as "triple bottom lines" in corporate sustainability reporting. When sustainability is understood as progress in all three dimensions at the same time, negative numbers on the three bottom lines are indicators of unsustainable outcomes.

\section{Interviews in northern Norway}

To identify risks perceived by stakeholders in the local development of bioenergy chains, 13 semi-structured interviews were conducted with strategically selected actors in the bioenergy value chain in Troms County in northern Norway in $2015 / 2016$. Our aim was to get perspectives from different stakeholders on wood-based bioenergy in the region.

Qualitative methods follow a different logic than statistical methods, generalizing from a sample to a population. Qualitative methods provide an understanding of a specific phenomenon that is more or less transferable as an explanatory model for a similar situation or phenomenon. In our case, this involves the interpretation of interviewee answers as perceived risks associated with the development of bioenergy chains.

While the quality of data in quantitative methods and analyses is assessed in relation to reliability, validity and generalization, the quality of qualitative data is assessed in relation to credibility, verifiability and transferability. The results of our interviews may thus not be representative for Norway but represent different opinions and understandings that may be relevant for other Norwegian and Nordic regions.
The selection criteria were that the group should consist of actors from the whole value chain. Conversations were carried out with contractors, loggers, municipal employees and residents who live close to central heating plants.

The plan for the interviews was notified to and approved by the Norwegian Centre for Research Data (NSD). The registration and approval ensured that the study was carried out in accordance with the ethical guidelines of The National Committee for Research Ethics in the Social Sciences and Humanities.

The aim of the qualitative interviews was interpretation and understanding of how and why, not questions of how much or how many. Conducting interviews gave us the opportunity to gather and investigate the interviewee's subjective interpretations of sustainability risk related to wood-based bioenergy in Troms County in Norway. The semi-structured approach gave the interviewees the opportunity to elaborate their answers, not pre-categorised in the interview schedule. In addition to an introduction, the interview guide was structured around seven topics:

- Introduction and presentation of the project

- How has cooperation on bioenergy developed in the region?

- How have conflicts of interest been solved?

- How has the regional market for bioenergy been established?

- What roles have local and national authorities played in the development of bioenergy in the region?

- How have environmental issues been solved?

- Has a potential for positive community effects of the industry been experienced? 

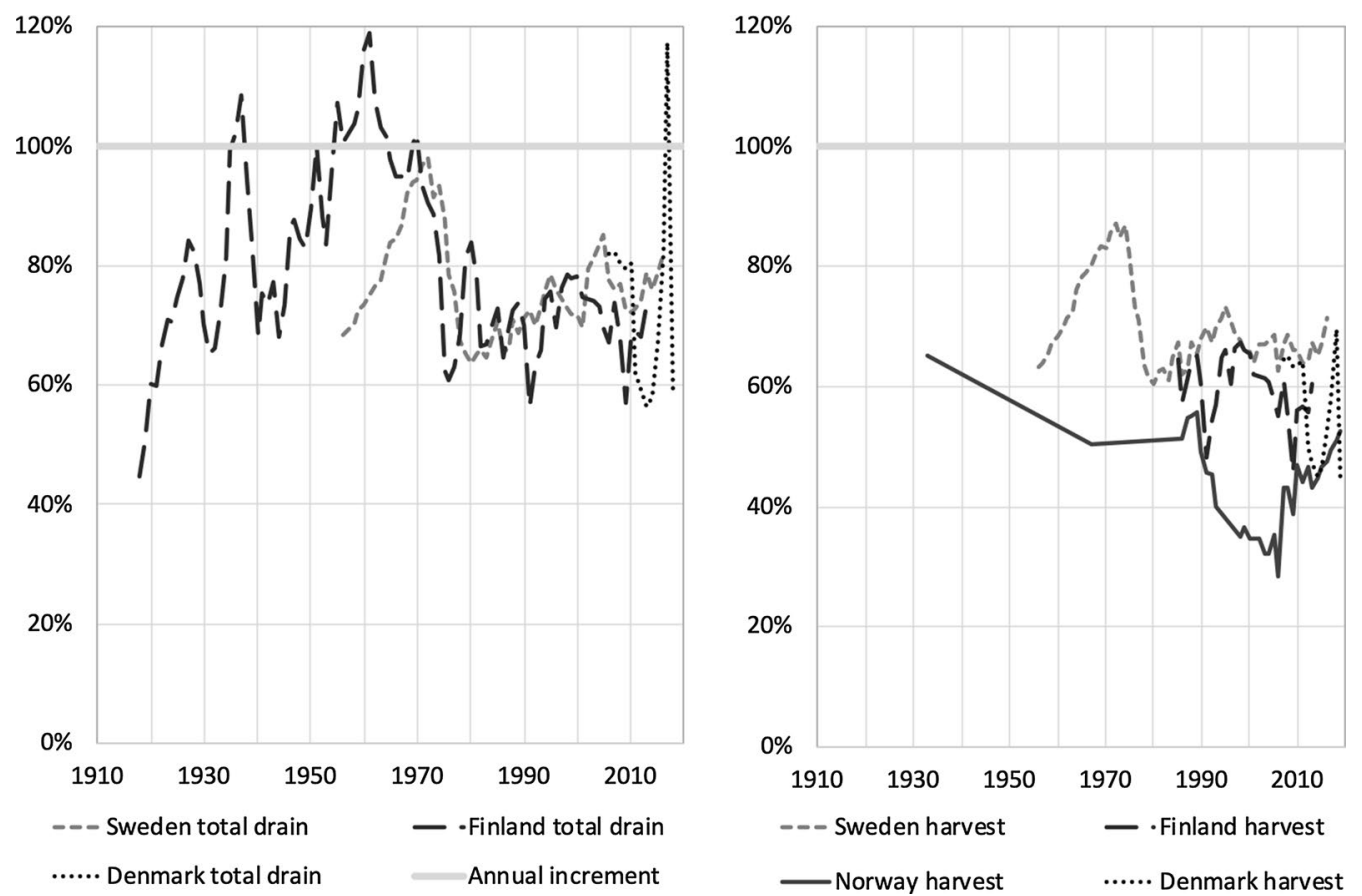

Fig. 3 Harvest volume and total losses in percent of annual increment in Sweden, Finland, Norway and Denmark, 1918-2019. Total losses (drain, term used in Finland) = harvest volume + losses of living trees by storms, forest fires, age and other natural causes. Left: total losses (drain); right: harvested volume. Source: authors' calculations based on data from [117-120]

- What key challenges for the further development of the bioenergy industry in the region have been experienced?

The dynamics of the interview situation decided the order of topics that was probed. Understanding of sustainability risks of bioenergy was an integrated perspective in the conversations. We used audio recorders during the interviews, and their transcriptions were preserved in anonymized form. The review of the interviews was largely based on parallel transcription and analysis. Some of the interviews were partially transcribed, while others were summarized more in key words as we listened through them. The closer we got to an understanding that there was risk we studied, the less we transcribed long passages. We then searched the interviews for descriptions of risk related passages that could develop the understanding of risk.

The challenge with unstructured interviews is that the analysis becomes complex with many threads and scattered blocks of important information. For this reason, we have reproduced the quotes with mild linguistic editing ([44], pp. 243-4).

\section{Results and discussion}

Risks of deforestation, forest degradation and reduced wood supply

In the political bioenergy debate the risk of deforestation and forest degradation from bioenergy production is in focus $[17,45,46]$. Deforestation and forest degradation imply loss of all forest ecosystem services including the role as a carbon sink. Historically, this risk has been managed by applying the principles of sustainable forest management. The principle of harvesting less than the annual increment has been consistently applied in the four countries since World War 2 (Fig. 3). Theoretically, harvest rates below $100 \%$ can be extracted from the forests indefinitely.

Increased use of wood biomass for energy has not led to deforestation or a declining stock of timber. The annually harvested volume has consistently been lower than the annual increment by a wide margin (Fig. 3) and cleared forest areas have been rejuvenated. In addition, the four countries have completed ambitious afforestation programmes expanding the forest area and thereby recovering from preindustrial deforestation (Fig. 4). The results of these programmes are now seen as large 

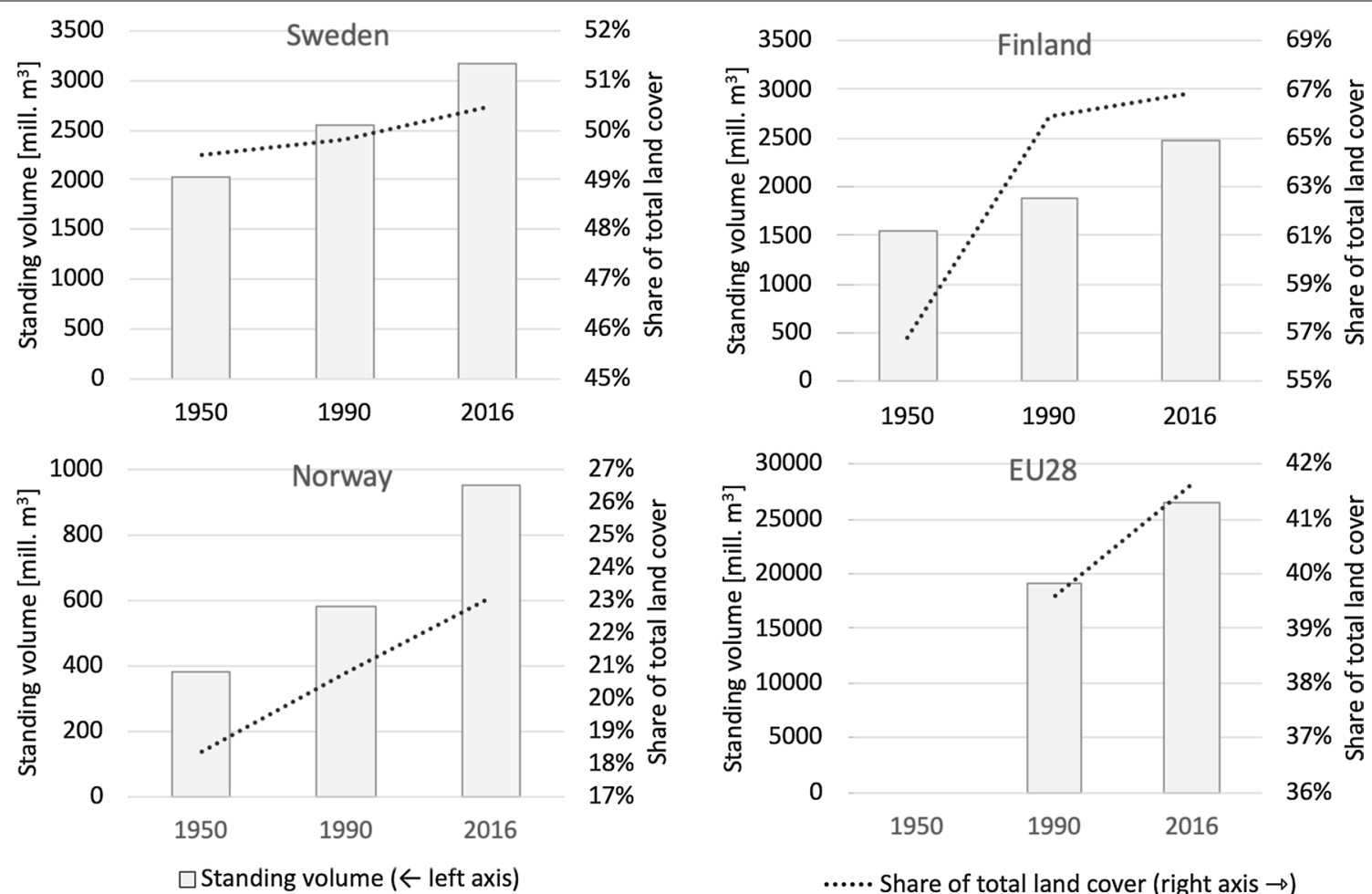

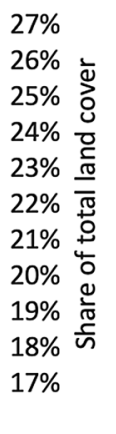

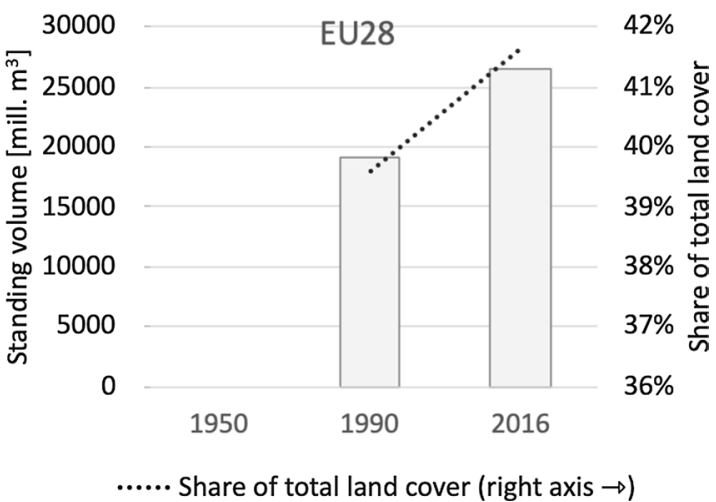

Fig. 4 Standing volume of productive forest $\left(\right.$ million $\mathrm{m}^{3}$ ) and productive forest area in percent of total land cover in Sweden, Finland, Norway and the EU, 1950-2016 (or nearest year with available data). Productive forest area generates at least $100 \mathrm{~m}^{3} /$ ha per year but is not necessarily harvested. Source: authors' calculations based on data from [99, 121-128]

cohorts of mature timber stocks, enabling higher, but still sustainable, harvest volumes.

In Sweden, Finland and Norway as well as the EU as a whole, the standing volume of timber increased not only from 1950 to 1990, but also in 1990-2016, when the use of bioenergy expanded considerably.

\section{Risks to carbon stocks}

The risk of releasing carbon stored in forest biomass to the atmosphere has been addressed in the conceptual framework of a "carbon debt" and its "pay-back time". The original use of the "carbon debt" concept referred to permanent clearing of natural forest making way for fields for energy crops. The carbon debt is the gap between this one-time release of $\mathrm{CO}_{2}$ from forest carbon pools and the cumulated emissions that are avoided by substituting petrol and diesel with biofuels based on crops from the fields. It can take up to centuries for these cumulated emissions savings to close the gap. This is referred to as the "pay-back time" [47]. This conceptual framework has, however, also been used to claim that forest-based energy always or for the most part leads to loss of carbon pools $[10,11,41,42]$.
The debt and pay-back analogy borrowed from economics is an apt analogy describing the harvesting and rejuvenation phases of the cycle of harvesting, rejuvenation and growth to maturity. Describing the cycle in full requires the completion of the analogy with the accumulation of "carbon worth" while paying back the carbon debt. The net emissions of a forest area to the atmosphere depend on the balance between the part of the forest area that is felled (releasing $\mathrm{CO}_{2}$ and incurring carbon debt) and the part of the forest area that still grows (removing $\mathrm{CO}_{2}$ from the atmosphere and building carbon worth). Removing and emitting the same quantity of $\mathrm{CO}_{2}$ from the cycle in a given area is equal to keeping the carbon pools in the area constant. The net emissions from a given forest area are negative when removals exceed emissions and can be inferred from changes in carbon pools.

The risk of carbon loss from soil carbon pools due to forest clearing is difficult to assess for several reasons. Increased decomposition in the soil organic layer may lead to a reduction in the carbon stored there, although this may be compensated by increased organic carbon in the mineral soil [48]. The long-term impact of whole-tree harvesting for bioenergy on soil organic carbon (SOC) 
stocks in boreal and northern temperate forest ecosystems is often, although not always, negative compared to conventional stem-only harvesting [49] and there is still a need for more knowledge on the controlling factors. Stump harvesting, which is practised largely in some areas of Finland, can reduce the SOC pool in the short term, although longer-term experiments (32-39 years) could not verify any significant SOC decline [50].

The net emissions including changes in biomass and soil carbon pools are, however, negative in Sweden, Finland, Norway and Denmark. The uncertainties in the risk assessment will probably not change the overall result, that net emissions despite high and increasing use of wood for bioenergy have been negative in all four countries (Fig. 5).

Figure 5 shows that the carbon pools of forests have been growing alongside the growth of bioenergy consumption. Net emissions from forest have been negative in Sweden, Finland and Norway since 1990. The carbon debt incurred by felling has thus been more than balanced by the carbon worth gain, despite the increasing use of biomass for energy. These macro-level results are consistent with the micro-level forest rotation where phases incurring debt and accumulating worth alternate. Wood flows are carbon neutral as long as the $\mathrm{CO}_{2}$ released from forest stands where felling incurs carbon debt does not exceed the $\mathrm{CO}_{2}$ absorbed by the forest areas that are not felled but accumulate carbon. The risk of incurring a carbon debt is primarily managed by keeping harvest volumes at a sustainable level and continuing the rotation by replanting.

Deforestation and afforestation play minor roles for net emissions in the four economies. Deforestation has primarily been due to urban expansion, infrastructure and in some cases, conservation of open areas and crop rotation with Christmas trees [51].

The carbon stock in harvested wood products (HWP) has also increased during the same period. Harvested wood products are products such as construction parts, furniture, paper and board, plastics and chemicals made from wood as feedstock. This carbon pool is, like the carbon pools in forest areas, part of the overall carbon storage.

The sum of all these changes to the carbon stock is shown as the total forest related net emissions (dotted curve in Fig. 5). These may be compared to the smokestack $\mathrm{CO}_{2}$ emissions from bioenergy to assess the risk that increasing bioenergy production causes reduced forest carbon pools and thus increased atmospheric $\mathrm{CO}_{2}$ concentration. Please note that in Fig. 5, these smokestack emissions are given in both net emissions and $\mathrm{CO}_{2}$ emissions from biomass. Neither a higher harvest volume nor the increasing biomass combustion is accompanied by positive net emissions or loss of carbon pools in any of the Nordic countries or the EU as a whole (Table 2).

According to the UNFCCC, Denmark's forests existing since 1990 have appeared as minor net emitters in some years, However, methodologies are being revised to correct mistakes and smoothen annual fluctuations by use of smoothened averages. These changes will be implemented in the reporting for 2021 (Vivian Kvist Johannsen, pers. comm.), with yet unpublished estimates being provided here in Fig. 5 and Table 2. The forest age and carbon stocks are currently increasing in Denmark [52], due to larger amounts of afforestation since the 1950s. Together with continued implementation of the 1989 plan of doubling the forest area, this might counteract the effects of postponed harvesting in old beech forests in the future. The postponed harvesting means that an accumulated amount of mature trees is available for felling that will expectedly take place in the coming decades [53].

It is a political rather than a scientific question which territory, over which time periods and which level of carbon accounting category, the carbon pools shall be non-declining to be considered sustainable and the biomass from it carbon neutral. Each country has committed itself to "conserve and enhance" carbon sinks such as forests, biomass and other sinks ([54], Art. 4.1.).

If all countries do that on the territory of their jurisdiction, then the carbon pools of the global biosphere will stop declining and start to increase. The Paris agreement reiterates these commitments and formulates the $1.5{ }^{\circ} \mathrm{C}$ target for the balance between emissions by sources and removals by sinks. Specifically, the countries are encouraged to implement sustainable management of forests and to enhance forest carbon stocks ([55], Art. 2.1, 4.1, 5.1-2). The EU has adopted a Land Use, Land Use Change and Forestry (LULUCF) accounting regulation committing every member state to "ensure that emissions do not exceed removals" for the land-use sectors as a whole (agriculture, forests, wetlands, grasslands) in each of the periods 2021-25 and 2026-30 (the "no debit rule") ([56], Art. 4). The implicit sustainability criterion here is that the carbon sinks of the entire territory of a member state should be non-declining. The LULUCF regulation, however, opens for some flexibility for member states which are not able to meet this commitment ([56], Art. 24). In Denmark, meeting the commitment is a challenge, in particular in 2021-25 as agriculture is a source of large greenhouse gas emissions. Emissions from forest remaining forests are expected to exceed removals in the 2021-25 period as a consequence of deficient afforestation in the previous decades [53]. An ambitious afforestation target from 1989 was far from met in the subsequent decades and the carbon accumulation on the areas that 


\section{Sweden}

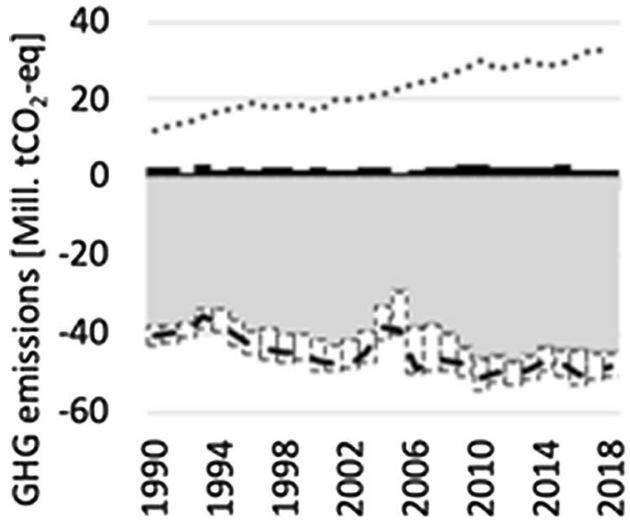

Norway

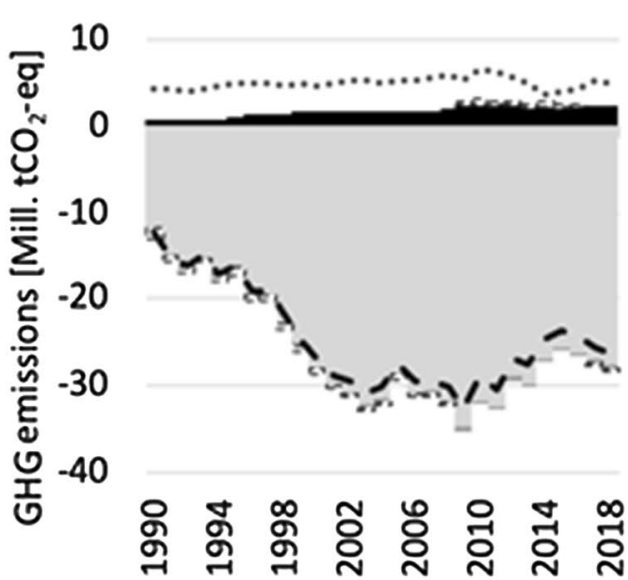

EU

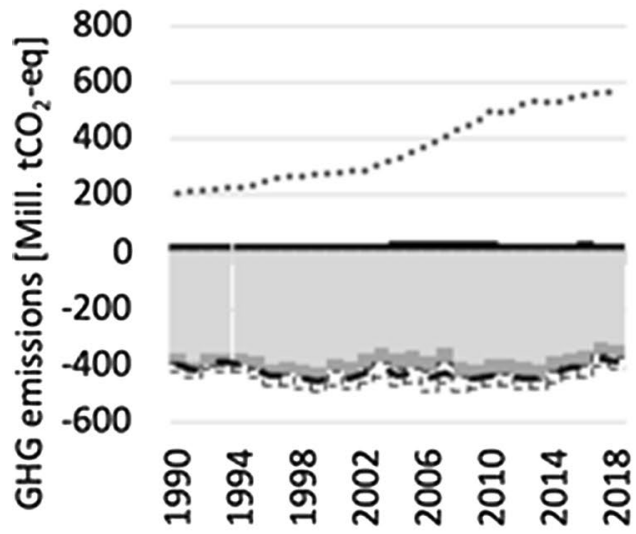

Finland

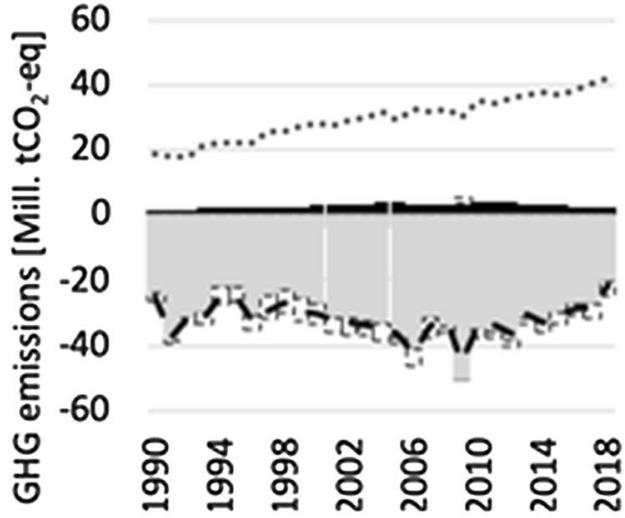

\section{Denmark}

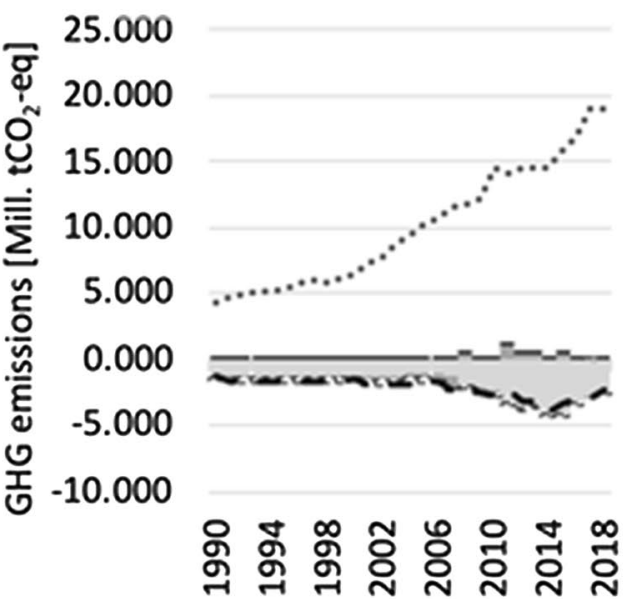

Existing forest net emissions

Harvested wood products (HWP)

Deforestation

Afforestation

Biomass combustion

- - Forest and wood net emissions

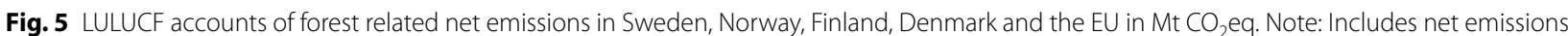
from forests remaining forests, afforestation, deforestation and harvested wood products. The data on net emissions from forests remaining forests and harvested wood products for Denmark have been revised and will be published in 2021. Note also different scales on the vertical axis. Source: authors' calculations based on UNFCCC data [129] 
Table 2 Cumulated forest related net greenhouse gas emissions ( $\left.\mathrm{Mt} \mathrm{CO}_{2} \mathrm{eq}\right)$ from forest remaining forest, afforestation, deforestation and harvested wood products, over decades and the period 1990-2018 in the EU, Sweden, Finland, Norway [129] and Denmark (pers. comm. Vivian Kvist Johannsen, University of Copenhagen)

\begin{tabular}{lrrrr}
\hline Country/region & $\mathbf{1 9 9 0 - 2 0 1 8}$ & $\mathbf{1 9 9 0 - 9 9}$ & $\mathbf{2 0 0 0 - 0 9}$ & $\mathbf{2 0 1 0 - 1 8}$ \\
\hline European Union & $-12,361$ & -4207 & -4383 & -3771 \\
Sweden & -1303 & -408 & -453 & -442 \\
Finland & -928 & -295 & -356 & -277 \\
Norway & -710 & -176 & -296 & -238 \\
Denmark & -62 & -16 & -19 & -27 \\
\hline
\end{tabular}

should have been afforested to balance the $\mathrm{CO}_{2}$ emissions from harvesting the now mature forest planted by still earlier generations is now missing.

When net emissions from existing forests are negative by a wide margin, it is a direct consequence of keeping harvest volume lower than the annual increment persistently through decades. This forest management principle leads to a sustained capacity of a forest area to supply a constant harvest volume. It is by and large the same principle that makes wood from such a forest area carbon neutral. The rotation is in itself carbon neutral and a forest area representing a sum of cycles in different phases can deliver a constant flow of carbon neutral wood, if there is a balance at any point of time between rotations in the growth phase and rotations in the harvesting phase. In isolation, the effect on net emissions of increasing the harvested volume of roundwood is a reduction of the carbon pools and an increase in the net emissions. However, the forests are still sustainably managed if their standing stocks of timber and carbon are maintained or even grow at the landscape level, with this balance being important in a longer planning perspective.

Figures 3, 4, 5 show how the four countries and the EU have succeeded in overall sustainable management of their forests, if this is measured by the considerable growth of the standing stock and its carbon pools.

Possible scenarios include many possible sustainable harvesting rates. Reducing the harvested volume by one million cubic metres will reduce the $\mathrm{CO}_{2}$ emissions from harvesting and increase forest carbon pools. Thus, there is a marginal trade-off between the harvested volume and the stored carbon.

This trade-off has been the subject of many studies applying ad hoc estimates of carbon pool changes and of the carbon content of harvested wood volume. Here, we analyse the trade-off comparing macro-level scenarios developed for the national forestry accounting plans for Sweden, Finland and Norway [57-59]. In each country, the scenario with the highest harvest volume is the maximum sustainable harvest, i.e. the maximum harvest that can be taken out of the forest annually without reducing the standing stock of timber. In recent decades, the countries have harvested only around $50-70 \%$ of maximum sustainable volume (cf. Figure 3). In addition to the maximum sustainable harvest scenarios, the analysis includes business-as-usual scenarios continuing these harvesting rates and scenarios with higher emphasis on biodiversity and cultural services of forests with even lower harvesting rates. Figure 6 shows the result of a standard OLS regression analysis of the trade-off between removals (additions to the carbon pool) and harvest volume (extractions by logging) in scenarios generated for each country. The regression coefficient reflects the ratio of changes in removals to changes in the harvested volume.

The results show a clear trade-off between the change of harvest volume and the change of forest carbon pools. It is, however, not a trade-off between sustained or diminishing carbon pools. The trade-off represents a choice between alternative sustainable scenarios, in all of which removals of $\mathrm{CO}_{2}$ from the atmosphere exceed emissions of $\mathrm{CO}_{2}$ to the atmosphere. Lower harvest volumes in some of the scenarios are the result of either lower timber demand or lower supply due to political decisions on conservation or setting larger areas aside.

The results in Fig. 6 show that a high growth of forest carbon pools can be consistent with high and even increasing harvesting volumes. Marginally, however, the negative sign of the regression coefficient, which is consistent across countries, shows that a higher harvest volume involves a risk of not a loss but of a smaller growth of carbon pools, i.e. less addition to them. Beyond this finding, the parameters should be interpreted with caution as the set of scenarios included in the analysis was not necessarily the complete set of alternative options in the strategic choice-set. The regression coefficients are not comparable since the forest planning models apply different definitions and assumptions. Notably they differ by definition of the $\mathrm{m}^{3}$-unit, by the assumed impacts of global warming on timber stock growth and by the impact of clearing on soil carbon pools. It is possible to manage this marginal risk of smaller growth of carbon pools by combining scenarios.

The harvest volume is a measure of not only the flow of wood out of the forests, but also the flow of wood through the economy where it is used, reused and disposed of. This human-controlled part of the biosphere has been called the econosphere [60], the anthroposphere or the technosphere as a macro-level concept corresponding to the micro-level life cycle concept. This more holistic perspective is important in the analysis of how harvest rates affect the carbon exchange between 


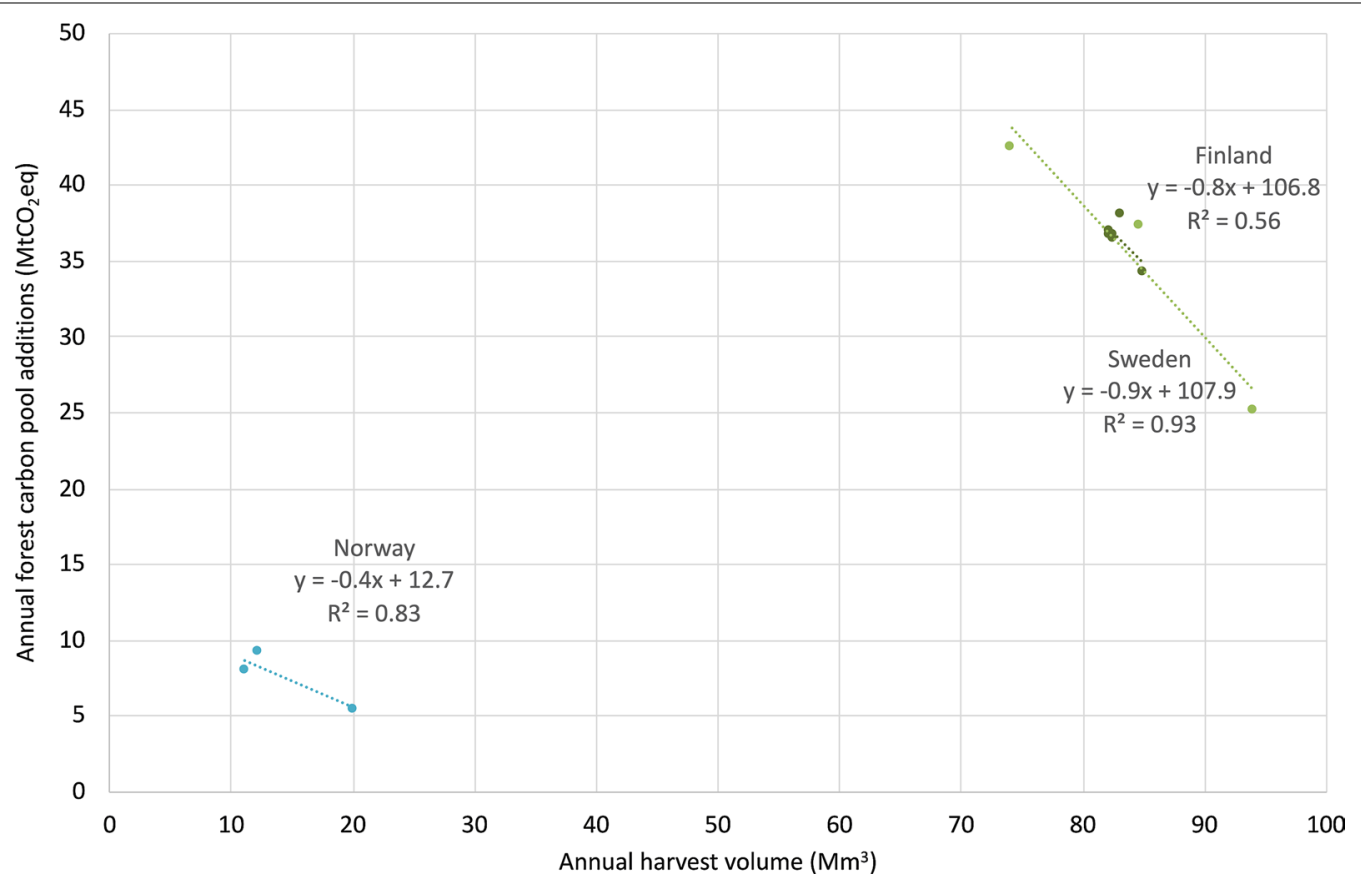

Fig. 6 Alternative harvest volume scenarios and implied annual storage in wood carbon pools in Sweden (right, 2021-25), Finland (centre, 2025-34) and Norway (left, 2026-30). The volume units are directly comparable between the countries. Carbon storage includes carbon stored in harvested wood products. Source: authors' calculations based on data from [130-133]

the biosphere and the atmosphere. The pool of carbon in harvested wood products flowing through the economy is already included in the carbon pool data analysed above (Figs. 5, 6). In addition, there are important substitution effects of using wood products rather than mineral products with a higher energy requirement in production and of using wood biomass as fuel. These effects have been measured with displacement factors [61, 62] and substitution factors [63]. Taking an average of 51 studies, Leskinen et al. [63] suggest a default substitution effect of the use of wood in the economy of $1.2 \mathrm{tC} / \mathrm{tC}$ in the harvest volume (including all biomass from forests). The studies, however, report a wide range of substitution effects from different uses. Thus, the impact of a marginal change in the harvest rate may differ according to the industrial demand causing it. Substituting mineral construction materials, plastic packaging or fossil feedstocks for plastics and other chemicals may have very different substitution effects. Moreover, the degree of development of the circular bioeconomy is important, due to thermodynamic fundamentals. If wood biomass is used first as feedstocks for the above products, then recycled and then, finally, used to produce fuels or biogas, then the aggregate substitution effect will be higher than if it is used initially for energy. Finally, the disposal of wood biomass after use and recycling is important. If it is disposed of to landfills, it represents a carbon pool until it decomposes and releases its greenhouse gases to the atmosphere. If it is used as fuel for district heating, it substitutes fossil fuels or electricity which in turn can substitute fossil fuels. Sweden, Denmark and Norway have banned deposition of biological waste and thereby generated a market with negative prices for combustible waste supplying combined heat and power plants [9].

Summing up, the risk of limiting the growth of carbon pools is not only managed by balancing strategic harvesting rates with afforestation programs, but also with strategies for developing the circular bioeconomy. The assessment of the climate impact requires a holistic analysis of not only the production and harvest of wood, but also its use, reuse and disposal.

\section{Frameworks for management of ecological sustainability risks}

With industrialisation, the supply and use of coal and steel lifted some of the unsustainable harvesting pressure off the forests. The following restoration of forests in the four countries, however, did not follow automatically, but was a result of carefully developed policies and institutional frameworks. In other words, the risks of deforestation, forest and soil degradation, and later biodiversity loss etc. were managed by laws, regulations and industry standards. Through the $19^{\text {th }}$ and early twentieth centuries provisions for sustainable forest management were 
gradually laid down in forestry legislation in the Nordic countries, such as the 1903 Forest Act in Sweden [64], the 1932 Forest Protection Act in Norway [65], the 1886 Forestry Act in Finland [66] and the Forest Conservation Act of 1805 in Denmark [67]. Provisions on replanting or natural regeneration after felling and sustainable harvest volumes have been further developed since then and the concept of sustainable forest management has been expanded to cover other services of forest ecosystems such as regulation of hydrological flows, biodiversity and space for recreation. Together with afforestation programmes, these measures have created the large standing forests in Finland, Sweden and Norway that are becoming ripe for felling in the coming decades. In Denmark, afforestation and reforestation have been continuously ongoing since the late eighteenth century [68]. After reaching a low point of $4 \%$ at the beginning of the nineteenth century, the forest cover had grown to $12 \%$ in 1989 , when it was decided to double the forest area by the end of the twenty-first century. A rate of $3000-4000 \mathrm{ha} / \mathrm{yr}$ is estimated in the coming decades (Vivian Kvist Johannsen, University of Copenhagen, pers. comm.) Through most of the $20^{\text {th }}$ Century, regulation was largely prescriptive with a focus on production of raw materials for the wood industry. It might be assumed that this approach would provide the most effective means of guaranteeing sustainability for the consumer. However, since the later part of the century, there has been a trend towards deregulation together with additional mandatory environmental goals [69]. This trend could be due to the increasing complexity of the goals to be achieved, with multiple goals making it difficult to regulate prescriptively, especially on a local scale, and increasing the risk of unintended effects [70, 71]. In a European or global perspective, there are contrasting approaches between countries, with some favouring a more prescriptive approach while others, including the Nordic countries, rely more on voluntary market-based approaches [71].

The most important European legislation on the sustainability of forest-based energy is the common European Economic Area (EEA) legislation, notably the renewable energy directive [43] and the ILUC/fuel quality directive [70]. The renewable energy directive states in the preamble $(\$ 102)$ "Operators should take the appropriate steps in order to minimise the risk of using unsustainable forest biomass for the production of bioenergy. To that end, operators should put in place a risk-based approach. In this context, it is appropriate for the Commission to develop operational guidance on the verification of compliance with the risk-based approach by means of implementing acts". This approach differs from that of the renewable energy directive from 2009 [72], which did not accept risk-based approaches to show compliance with sustainability requirements for liquid transportation biofuels.

Imported forest biomass may be more vulnerable to sustainability risks due to lack of transparency upstream in the supply chain. These risks are managed with provisions in the renewable energy directive ([43], p. 6) requiring biomass harvested from forests to comply with basic principles of sustainable forest management, including regeneration and maintaining the long-term productive capacity of the forest. The EU Timber Regulation [73] uses a risk-based approach to minimize the risk of illegally harvested timber and timber products entering into the EU market and requires buyers to implement a due diligence system. The Forest Law Enforcement, Governance and Trade Action Plan [74, 75] aims at preventing bioenergy supply chains originating in unsustainable forest management and the EU Commission has launched an initiative to improve these instruments for EU importers of biofuels [76]. National legal requirements have also been developed in some European countries [77]. In Denmark, sustainability of biomass for energy was governed by a voluntary agreement and system from 20162019, but a political agreement was made in 2020 to put it into a legal framework with additional requirements [78].

European forest managers may choose to be guided by a range of forest management or biomass standards, including the Programme for the Endorsement of Forest Certification (PEFC) [79], the Forest Stewardship Council (FSC) [80], the CEN and ISO standards for sustainably produced biomass for energy applications [81, 82], and the criteria and indicators of intergovernmental cooperation bodies such as Forest Europe [33]. The standards overlap to a large extent and provide guidance on how the overall EU sustainability criteria can be implemented. In the Nordic countries, PEFC certification covered 49, 80, 57 and 30\% of the total forest area in Denmark, Finland, Norway and Sweden, respectively, while FSC certification covered 39, 2, 2 and 37\% respectively, in data collected in 2014 [83]. Thus, it appears that different certification systems are prevalent in different countries, although the reason for this is unclear. According to Maesano et al. [83], 72\% of Finnish public forest and 90\% of Finnish private forest were certified in 2015 .

An alternative to forest management unit (FMU)-based certification systems such as PEFC and FSC is a certification based on a risk assessment of the sourcing area, region or country, in which verification of low sustainability risk is conducted as a desk audit, with requirements for additional documentation for indicators assessed with specified risk [71]. As stated above, the renewable energy directive [43] accepts a risk-based approach. Certification systems that use national and regional risk assessments, 
such as the Sustainable Biomass Program (SBP) [84], are already accepted for showing compliance with national sustainability criteria in some EU member states, including Denmark, and, temporarily, the Netherlands, as well as in the UK [71]. The FSC uses risk assessment in its "Controlled Wood" certification, which is used to control uncertified forest materials from the assessed area so that those materials may be mixed with FSC-certified materials and used in products that carry the FSC Mix label [85]. It is not known whether sustainability goals are achieved more effectively through FMU- or risk-based approaches to verification [71]. It should be noted that FMU-based verification will in practice also involve an element of risk assessment, as a full auditing of all indicators is impractical [71].

Currently, national or regional forestry related risk assessments are conducted to show compliance with the EU Timber Regulation for legality [72, 86], Forest Stewardship Council (FSC) Controlled Wood [85], and SBP certification [84]. Some certification bodies, such as Preferred by Nature (previously NEPCon) [87], handle all three types of risk assessment, as well as FMU level certification under FSC and PEFC. Requirements for different certification systems overlap, so databases built for verification of compliance with one system's standards might be used to show compliance with other systems' standards, even if there may be differences in the required stringency [71].

\section{Economic sustainability risks}

We consider two classes of structural economic risks. First, the risk of developing a suboptimal renewable energy economy and delaying the deployment of the best performing solutions. This risk can be framed as a risk of picking inferior solutions in a "picking the winner" dilemma and of a subsequent technology lock-in. Second, the risk of affecting demand in ways that distort markets and compete for resources with food and feed production and with the new circular bioeconomy solutions.

The transition to renewable energy involves an innovation race, not only between renewable and non-renewable energy, but also between the various renewable energy solutions. The major renewable energy technologies beside the already developed hydropower technology include wind, solar and biopower. The primary competitiveness parameters include low costs per energy unit and low losses of neighbourhood or landscape values. The development of these technologies depends to a high extent on the government instruments directing the transformation. If government support schemes favour one technology over the others, there is a risk of a technology with inferior performance crowding out better performing technologies. This may even lead to lock-in of inferior or transitory technologies making it difficult to correct the misdirected development. The economic gains of innovation will then not materialise.

Through the 2010s, the cost competitiveness order of wind, solar and bioenergy has reversed. Globally, average levelized costs of electricity (LCOE) of newly installed photovoltaic (PV) power plummeted from 0.38 USD/ $\mathrm{kWh}$ in 2010 to $0.07 \mathrm{USD} / \mathrm{kWh}$ by 2019 . Onshore windpower costs were halved from 0.10 to $0.05 \mathrm{USD} / \mathrm{kWh}$ in the same period. Biopower, however, only declined from 0.08 to $0.07 \mathrm{USD} / \mathrm{kWh}$ [88]. The four countries have managed this kind of risk by developing technology neutral support schemes for power from renewable sources. Already in 2003, Sweden introduced an electricity certificate market where certified electricity suppliers could compete for market shares that the electricity distributors were obliged to buy. Norway joined the scheme in 2012, but did not certify power producers using fuel combustion technologies [89].

Denmark supported renewable electricity with technology specific schemes until the introduction of technology neutral tender for wind and PV suppliers by 2018 . The average subsidy needed for wind and PV projects in Denmark in 2018 was $€ 3$ per MWh [90] and only $€ 2$ per MWh in 2019 [91]. Power generation in coal power plants converted to biomass had been subsidised with $€ 20$ per MWh. These subsidies were abolished for new plants, whereas already granted subsidies continue until the plants are written off $[92,93]$. According to the Danish Energy Agency, it is very unlikely that biomass-based power will ever be able to operate under these conditions [94]. Similarly, Finland introduced a technology neutral feed-in premium scheme in 2019. The result of the first tender was that wind power projects won all of the licences to supply renewable electricity [95].

The system price on the NordPool market (the common power market for the four countries) has dropped from an average for 2004-2011 of €39.3 per MWh to an average for 2012-2019 of $€ 32.3$ per MWh. The lower prices are to a high degree the result of a larger supply of wind energy. This affects the dispatch of biopower generators and thus lowers the biopower share of the electricity market. In sum, with a technology neutral renewable energy support regime and low electricity prices, there is little risk of government support schemes misdirecting and locking in the wrong renewable energy technologies. The risk has been effectively managed.

The development of successors to fossil transport fuels represents a similar risk of locking in a technology with poorer properties in the long term than other solutions. Lithium-ion battery technology enables the anticipated wave of transformation to electric car transport in the 2020s. Solid-state battery technology is believed 
to enhance the range of battery powered transport significantly. Still, battery technology will probably not meet the energy and power density required by long-distance maritime transport, aviation, and some long-haul road transport. Advanced biofuels are one of the main candidates to meet this demand. The other candidates include hydrogen in some form used in combination with fuel cells and hydrogen combined with either nitrate to generate ammonia or carbon dioxide to generate synthetic hydrocarbons. The latter two solutions are known as Power-to-X or electro-fuels and are used to fuel combustion engines [96].

The innovation race between these competing solutions involves a "picking the winner" dilemma. On the one hand, innovation cannot proceed sufficiently fast without government support. On the other hand, any support for innovation involves a risk of locking in a solution which is inferior compared to the other solutions. If advanced biofuels succeed, they may require large quantities of wood as feedstocks. At the same time, the increasing competitiveness of non-combustible energy solutions tends to reduce the demand for wood for heat and power. The four countries participate in the international development of all three classes of technology; Sweden and Finland with higher emphasis on biofuels from waste streams from the forest industries, and Denmark with higher emphasis on Power-to-X solutions. The risks of support to a technology in excess of what is justified for innovation is managed primarily with the EU renewable energy directive [43], the state aid directive [97], and the taxonomy for sustainable activities [98] being adopted in 2021. When the alternative solutions have achieved the necessary degree of maturity, and are ready for commercialisation, they can be supported by a technology neutral scheme like the schemes for renewable electricity. In 2021, however, the technologies are still at an experimental stage, and the outcome of the innovation race is unknown.

The second class of economic risks associated with excessive use of wood biomass for energy is that the demand for wood will distort prices in connected markets with adverse impacts on costs in industries competing for the same resources. This risk is decreasing in proportion to the decreasing generation of power and heat based on biomass. However, if advanced biofuels are successful in the future, this will cause a large increase in the demand for biomass. The EU renewable energy directive includes provisions defining sustainable sources of biomass for biofuels in order to manage the risk of deforestation due to direct and indirect land-use change globally caused by European biofuel and bioenergy demand [43].
The business case for using wood biomass for energy is to use low value wood, i.e., wood with no or little alternative use and thus a very low price. Neither trunk parts below a minimum trunk diameter for pulp-wood nor tops, branches, small trees from thinning, stumps and roots, dead and damaged trees or trees with pests and pathogens meet the requirements for industrial processing to wood products. Waste or side streams from industrial processes including the energy rich black liquor, bark, sawdust and numerous other varieties of wood biomass are also suitable as fuels. In short, trees, logs and even sawn planks and boards contain biomass that will never be used as materials due to low quality but serves well as fuel. Consequently, the price of wood reflects the value of its energy content as well as the value of its content of fibre and chemicals suitable for further processing. The share of the materials fraction in the volume of processed wood increases as it advances through the processes in the supply chain. Its value increases as it becomes still more useful. The share of the energy fraction conversely decreases through the supply chain, whereas its value per volume unit probably increases due to lower moisture and higher purity. Generally, the price of wood varies with the demand of wood for energy as well as material use. The energy fraction links the wood price to the prices of energy substitutes, including fossil fuels.

At the stumpage level (before logging) the value of logs suitable for sawmills is several times larger than the value of energy wood (logs with no other use than energy). The risk of a high demand for biomass for energy use leading to an allocation of sawmill or pulp logs to energy use can be assessed by comparing the prices of wood for energy use and wood for other purposes. If the prices converge, it could be a sign of change in the market mechanisms directing the allocation of wood towards energy rather than materials.

However, despite the increasing demand for forest biomass for energy use, the Nordic timber markets and the price ratios between various sorts of timber qualities have been relatively unchanged through the recent past (Fig. 7).

The data from Finland show that the price relations are relatively stable. Forest owners selling saw logs as energy wood would lose on average $92-94 \%$ of the market value of their products. The value of pulpwood would be reduced by around $75 \%$ if it was sold as energy wood.

The area below the curve in Fig. 8 (right) shows the revenues generated by each class of Norwegian forest products. Most of the volume is pulpwood, but $70 \%$ of the revenue comes from sawlogs, $25 \%$ from pulpwood and $4 \%$ from mixed pulpwood and saw logs. Only $1 \%$ of the revenue comes from fuel wood. These figures are 


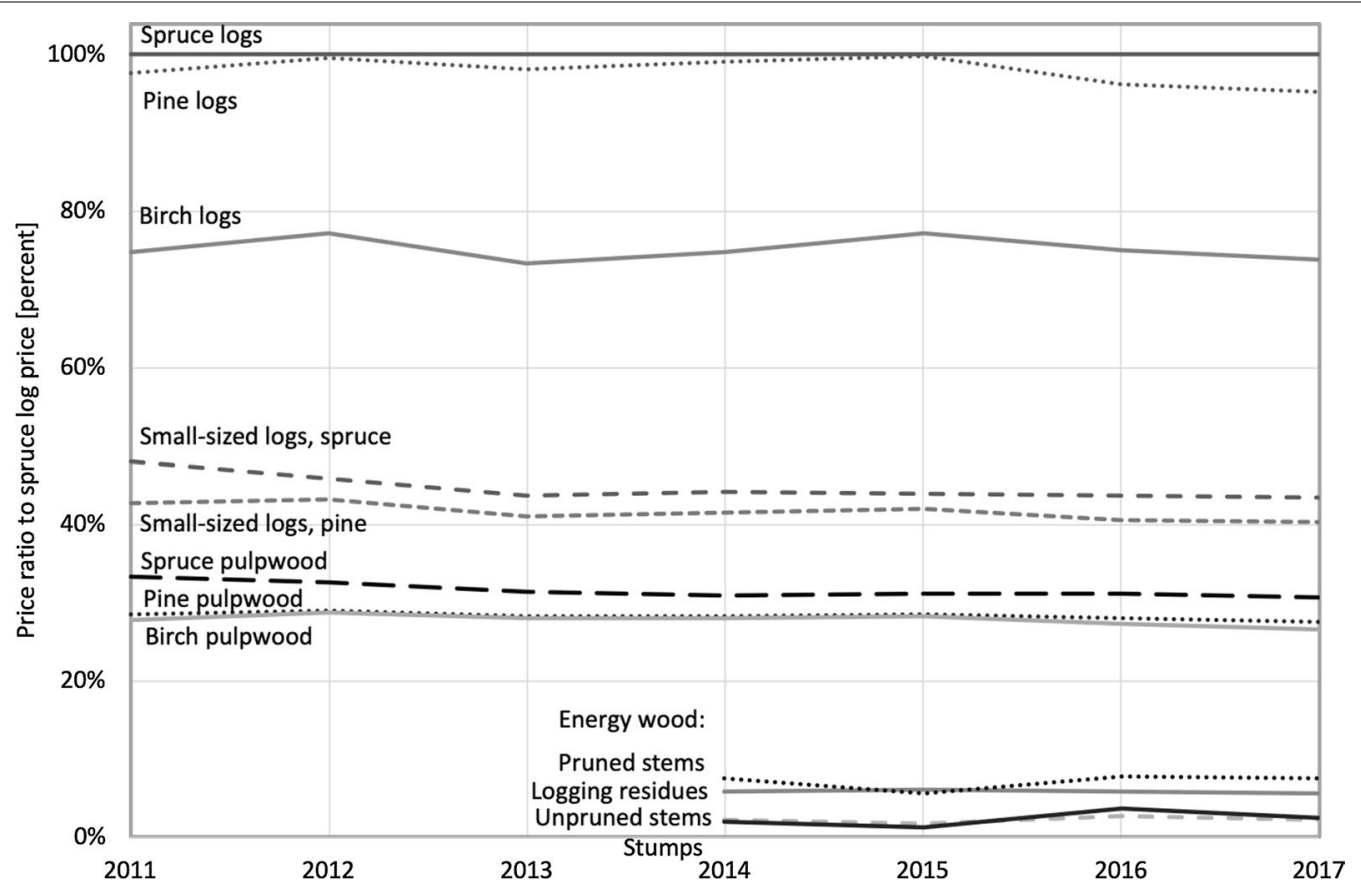

Fig. 7 Prices of roundwood and energy wood in \% of the spruce log price, Finland, 2011-17. Stumpage prices, i.e., before delivery costs. Source: authors' calculations based on data from [134]
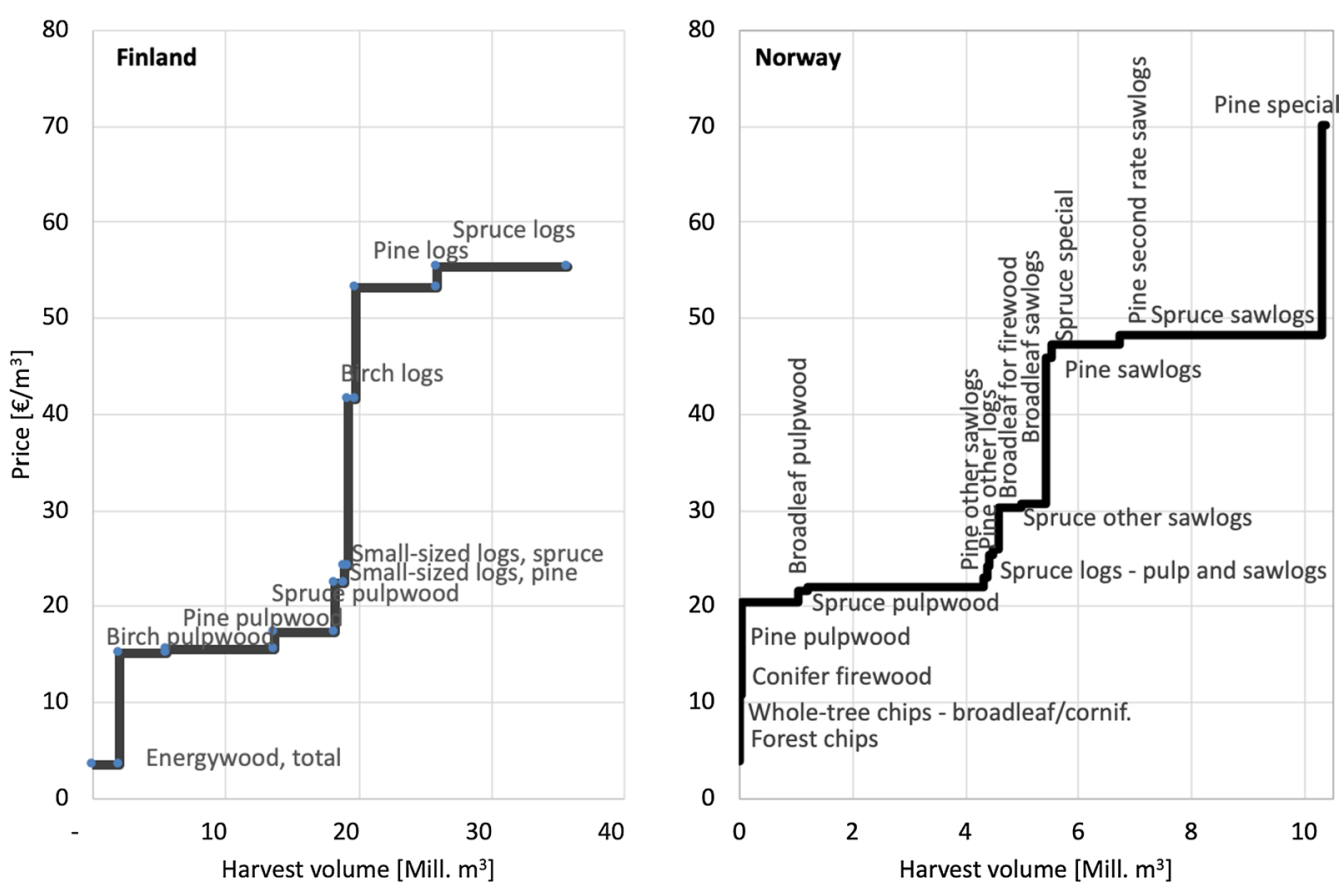

Fig. 8 Prices, harvest volume and harvest revenue (the area below the curve) by wood quality in Finland (left) and Norway (right), 2016. Exchange rate $€ 100=$ NOK 928.99. Source: authors' calculations based on data from [134, 135] 
very close to the similar data for Finland (Fig. 8, left). The volumes are the total standing sales and delivered roundwood, but at stumpage prices (that is, excluding delivery costs). The energy wood products (stumps, residues, pruned and unpruned stems) are only a few euros per cubic metre. This price would have to increase several times over to persuade forest owners to sell pulp wood as energy wood. The area below the curve represents the total revenue from roundwood and energy wood sales. Saw logs amount to $76 \%$ of the total revenue, pulpwood $21 \%$, small sized logs $2 \%$ and energy wood 1\% (data for 2014-18) [99].

The considerable and stable price gap between wood for energy and wood for material use according to Figs. 7 and 8 makes it unlikely that resource competition will be a serious risk at this level of the supply chains. Still, locally and on higher supply chain levels resource competition could yet occur. Transport costs are very high compared to stumpage prices and transport costs to various buyers may narrow the price gap locally. Wood industry waste can be a resource for both particle board and energy pellet manufacturing [100].

The four countries have experience with managing such risks. In Finland the subsidy for bioenergy (power) is reduced by $40 \%$, if the wood biomass is sourced from logs or pulpwood, requiring a diameter at breast height of maximum $16 \mathrm{~cm}$ for energy wood originating from felling sites of large-sized trees [101]. In Sweden, the Wood Fibre Act (1987-92) protected the security of supply of biomass to the pulp and paper industry in the face of the expanding bioenergy-to-grid value chains [102]. It was, however, abolished later as it was found to be at best obsolete and possibly distorting [100]. Since 1999, tall oil used for heating has been taxed in Sweden in line with heating oil to secure supplies to the chemical industry [102]. Now tall oil used for heating is also taxed in Finland [103]. These observations confirm that unintended resource competition may occur in limited markets but has been modest. Moreover, there are measures that can mitigate the risks and prevent an unsustainable outcome.

The European Commission found that the implementation of the National Renewable Energy Action Plans to 2020 would result in a supply gap for solid biomass. The supply gap would amount to $280 \mathrm{TWh}$ by 2020 , corresponding to $15 \%$ of EU primary bioenergy supply. However, the Commission asserts that the risk of a demand driven price increase is modest and can be managed by importing pellets from other countries [41]. Pellet prices did rise in 2017-18 but primarily due to temporary supply failure and not more than earlier fluctuations [104]. Thus, at least until 2020, the supply gap has been manageable.
The national energy and climate plan for Denmark stipulates a slightly declining demand for solid biomass for heat and power generation through the 2020s and 2030s [105]. The Swedish and Finnish governments expect a slightly higher demand corresponding to the increasing supply of biomass as sidestreams from industrial processes $[106,107]$. These expectations correspond to the expectations of a small and constant supply of biomassbased power to the NordPool power market $[108,109]$.

\section{Social sustainability risks}

Bioenergy has only indirect links to social imbalances. Any transformation to climate neutral energy solutions involves innovation costs. There is a risk that these are borne disproportionally by some particular groups such as district heating consumers paying high heating bills or low income households paying high energy taxes. On the other hand, bioenergy chains can provide jobs in rural regions where there is a gap between rural and urban income earning opportunities. Results on these aspects for Sweden have been published elsewhere [9].

\section{Bioenergy communities in a glocal context}

The bioenergy chains described in the introduction have been developed by different agents operating in different structures. Bioenergy-to-grid chains were primarily developed around district heating utilities by municipalities, biomass suppliers and in some cases citizen groups combining their entrepreneurial capabilities. The importance of such local entrepreneurial networks is now recognised in the EU's renewable energy directive as "renewable energy communities" [43] as distinct from large and established energy corporations. The directive lays obligations on member states to remove barriers and discriminatory practices curbing the actions of renewable energy communities. In the four Nordic countries, favourable conditions for renewable energy communities were already integrated in energy planning in the 1990s and 2000s. Hansen and Berlina [9] provide a description of the development of the sector in Sweden.

The motivating factors behind these bioenergy communities include local jobs and livelihoods, the local desire for climate-neutral energy, and reasonable heating costs, and they depend critically on local political support for which these objectives are important.

Robertson and others [110-112] criticize the understanding of globalization to only emphasize one specific route of development where cultural homogenization is dominant, and where micro-sociological or local conditions are ignored. The problem becomes that of spelling out ways in which homogenizing and heterogenizing tendencies are mutually implicative [112]. It is in the extension of the identification of this problem that Robertson 
introduces his concept of the glocal or glocalization. Glocalization is not about homogenization vs. heterogenization or universalization vs. particularization. It is meant as an analytical concept to move past this dichotomist way of thinking and rather to conceive them as reciprocal and complementary trends. A glocalized concept of bioenergy sustainability risk, linking transnational co-operation with local practice, is a theoretical challenge, but may be a useful framework for understanding the risks faced by bioenergy communities. When local entrepreneurial actors join forces to contribute to the mitigation of global risks, they face risks of economic and technical nature.

Albrecht [113] found that rationalities may shift according to level of governance and practice:

Norwegian and EU climate reports and strategies prioritize the goal of reducing carbon emissions. However, during their journey to implementation these strategies are often confronted with the shifting rationalities of various entities and a 'rationality jump' towards economic aspects ... is visible in the case of Norway. Bioheat development and its markets are largely based on economic considerations with only a few exceptions ( $p$. 392)

This shift in rationality may also be understood as a shift in the understanding of risk. As a bioenergy community approaches the actual investment in and operation of a bioenergy chain, the challenges become economic and technical.

Regarding economic risks, two of the studied communities formed on private or citizen initiative went bankrupt and had to be reconstructed by the municipality. Capacity building in economic and technical matters is important for the success of such bottom-up initiatives. Ecological risks in terms of local air pollution and heavy transport are risks when localizing a CHP plant, but the municipal authorities in the four countries are equipped with tools to remedy such risks. One of the risks that are perceived as very important to many of the interviewees is that the project does not contribute fully to local jobs and livelihood, but rather to profits of non-local investors. One example from Troms County is:

Some local politicians had strong focus on how wrong it could become, with smoke, smell and all the transport. The most active opponents represented the asthma and allergy organization. A year after it was established, however, it was stated in the newspaper that it was okay. Resistance may also have been linked to the fact that those who owned the new district heating plant came from outside, and that the local power company did not establish first.
This citation is an example of the complexity of risk as it opens for different understandings of the meaning of smoke, shifting between ecological and economic rationalities. In addition, it also relates to the distinction between the local community and owners from "outside". The first two sentences conventionally relate smoke to the unclean and pollution. In the third sentence smoke etc. are described as "okay". The last sentence opens for an alternative understanding of resistance to smoke, as smoke becomes a symbol and connotes unwanted economic activity by actors from outside the community. In other words: the resistance to smoke in the last sentence is resistance to the risk of disembedding activity [114], i.e. lifting economic activity out of the local and sociocultural context. We also found a related example when we asked about different ways bioenergy activity is supported economically from regional and national grants.

When those grants ${ }^{1}$ came in, and when you pour a lot of public money into an industry and it becomes a bit lucrative, there are some that see the opportunity. Some are doing well and others are doing something that is a bit on the edge. Some cowboys gladly see the opportunity to earn some money if there is a chance.

Several of the people we talked to in Troms addressed the topic of grant schemes. Some of these schemes were national, whereas others were regionally adapted. The "cowboy" metaphor was used by several interviewees relating it to the introduction of the grant schemes. In the beginning of our interviews, it was not clear to us where the "cowboys" came from. After some time, we understood that the grants attracted actors from outside the region with no social or cultural relationship to the area. "Cowboy" and "Wild West" were metaphors used in this situation to describe a condition they understood as lack of regulation and trust and that undermined their own embedded activity. This indicates distrust for national grant schemes as they are thought to not fit regional/ local natural and cultural conditions. It shows different approaches to bioenergy development that can be understood as embedded and disembedded, and it indicates that different actors in the bioenergy sector make use of different adaptive strategies.

Our examples show that, in Troms County, how people select, understand, act and adapt to risk has implications for the development of bioenergy communities. The understanding of risk in bioenergy communities should be understood as a combination of the global and the local. How to handle the tension between

\footnotetext{
1 "Energiflistilskuddet", an energy chips subsidy.
} 
global regulation and local practice of bioenergy is also a challenge for policy makers, regulators and technological entrepreneurs aiming for uniform policies and technologies.

The development of bioenergy in northern Norway is characterized by adaptation between tradition and innovation, and between the global and the local. Our examples from Troms show how chip-based bioenergy is socio-culturally adapted to regional and local conditions and forms of risk, and how these must be understood in close relation to ecological and economic conditions and perspectives.

The above economic, ecological and social risks at the local level may demotivate local actors and the local public; not only the actual risks but also the perceived risks. Perceived risks include the risks of economic failure, of environmental pollution and loss of local amenities and of non-locals capturing the economic gains of the project. If these local risks are not managed, the project is unsustainable in a governance sense. Capacity building, good physical planning tools for local authorities and local investment funds can be instrumental in managing the risks.

\section{Synthesis and conclusions}

We have examined the outcome of developing bioenergy chains as the sum of their sustainability risks and the management of these. In this perspective, the experience of the four Nordic countries is that the sustainability risks of bioenergy are manageable and have been managed so that unsustainable outcomes have been largely avoided at the general level. They may, however, occur locally, temporarily and in limited markets.

The increasing forest area and its reserves of standing timber store increasing pools of carbon despite the parallel development of bioenergy chains. We have shown how the risks of deforestation and carbon pool loss have been managed by sustainable forestry practices including the principles of letting tree stands grow to maturity, harvesting less than the annual increment and replanting after harvesting. Felling only implies a carbon debt for the forest as a whole when these principles are not followed. The scenarios for harvest rates show that there is a marginal trade-off between harvest volume and carbon pools even in countries with sustainably managed forests. The total climate impact of a change in harvest volume involves measuring this trade-off against the direct and indirect fossil fuel substitution caused by using the harvested wood biomass for products and fuels. Thus, it is recommended to accompany the harvesting strategy with a strategy of substituting fossil fuels and fossil fuel intensive products. Generally, a stronger pressure on ecosystems from harvesting of larger areas must be met with reinforced risk management measures based on scientific knowledge derived from experiments [49].

The development of bioenergy technologies involves economic sustainability risks that are not peculiar to bioenergy. Their dilemma is on the one hand that government support is necessary for the technology to develop, but on the other hand that government support may favour one technology, which may prevail although it is not the best performing technology. This risk has been managed by designing the support regimes with a sufficiently levelled playing field for commercialised renewable energy technologies. The other class of economic sustainability risks includes resource competition between energy and material uses of wood biomass from the various steps of the wood processing supply chains. The data did not reveal any serious convergence of prices for energy and material use wood. There thus appears to be little risk of a high demand for the energy fraction of the harvest distorting the prices and causing allocation of wood suitable for material use to energy use. This macrolevel result does not preclude distorting resource competition in local or special markets, but the four countries have demonstrated that these risks can be managed.

The bioenergy chains developed in the four countries would not have been developed without the institutional framework created by governments. This has not been prescriptive regulation but rather development of an institutional framework enabling local entrepreneurship in the context of bioenergy communities and municipal utilities. Managing the economic and social sustainability risks is important for the trust and acceptance required for such local action. Our interviews showed the importance of economic activity being locally embedded rather than being perceived to be for the benefit of "outsiders".

As risk in bioenergy communities is a combination of global and local factors, management of the tension between global regulation and local practice of bioenergy is a challenge for policy makers, regulators and technological entrepreneurs. Prescriptive regulation is unlikely to be the way forward in a Nordic context: risks must be managed with stakeholder involvement and empowerment at the local level in order to safeguard the legitimacy of bioenergy development, and tensions between globally and locally identified risks must be reconciled.

Natural science cannot see management principles, but they are real and important. Therefore, an interdisciplinary and holistic view comprising natural as well as social sciences is necessary for understanding the sustainability of bioenergy and carbon neutrality of wood. These states of human-nature interaction cannot be fully understood from a natural science or social science perspective alone.

The development of bioenergy entails risks of unsustainable outcomes although the development aims at a 
sustainable and climate neutral economy. We use the dimensions of sustainable development as an analytical framework for studying the sustainability risks. There are important sustainability risks in all dimensions of sustainable development. Whether these materialise as unsustainable outcomes, however, is a question of risk management.

\section{Acknowledgements}

We thank Knut Øistad, two anonymous reviewers, and Guest Editor Inge Stupak for valuable comments on the manuscript.

\section{Authors' contributions}

All authors participated in the writing and revision of this paper. $\mathrm{ACH}$ was responsible for the sections on economic sustainability and carbon sequestration, NC was responsible for the section on ecological sustainability, and AWH for the section on bioenergy communities in glocal risk society.

\section{Funding}

This work was funded primarily by the Research Council of Norway through the TRIBORN project ("Securing triple bottom line outcomes from bioenergy development and innovation in rural Norway", grant number 233640). Additional funding was received by NC from the network "Effects of bioenergy production from forests and agriculture on ecosystem services in Nordic and Baltic landscapes" (2015-03), funded by Nordic Forest Research (SNS) and the Nordic Joint Committee for Agricultural and Food Research (NKJ), and the Strategic Institute Programme "Forest Management for Climate Change Mitigation: Forest Carbon Dynamics", as well as from the Norwegian Institute of Bioeconomy Research.

\section{Availability of data and materials}

Not applicable.

\section{Declarations}

\section{Ethics approval and consent to participate}

The plan for the interviews was notified to and approved by the Norwegian Centre for Research Data (NSD). The registration and approval ensured that the study was carried out in accordance with the ethical guidelines of The National Committee for Research Ethics in the Social Sciences and Humanities.

\section{Consent for publication}

Not applicable.

\section{Competing interests}

The authors declare that they have no competing interests.

\section{Author details}

${ }^{1}$ Niels Brock Copenhagen Business College, Julius Thomsens Plads 10, 1925 Frederiksberg, Denmark. ${ }^{2}$ Norwegian Institute of Bioeconomy Research, P.O. Box 115, N-1431 Ås, Norway.

Received: 15 February 2019 Accepted: 21 April 2021

Published online: 07 June 2021

\section{References}

1. Government of Sweden (2017) Ett klimatpolitiskt ramverk för Sverige. Regeringskansliet https://www.regeringen.se/rattsliga-dokument/ proposition/2017/03/prop.-201617146/. Accessed 20 Jun 2019.

2. Government of Norway (2021) Klimaplan for 2021-2030. https://www. regjeringen.no/contentassets/a78ecf5ad2344fa5ae4a394412ef8975/ nn-no/pdfs/stm202020210013000dddpdfs.pdf. Accessed 30 Jan 2021.

3. Government of Norway (2017) Lov om klimamål (klimaloven). Lovdata https://lovdata.no/dokument/NL/lov/2017-06-16-60. Accessed 28 May 2021
4. Government of Finland (2015) Climate change act. https://www.finlex. fi/fi/laki/kaannokset/2015/en20150609.pdf. Accessed 26 Nov 2020.

5. Government of Finland (2020) The reform of the Climate Change Act. Ympäristöministeriö https://ym.fi/en/the-reform-of-the-climatechange-act. Accessed 26 Nov 2020.

6. Government of Finland (2020) Government programme. 3.1. Carbon neutral Finland that protects biodiversity. https://valtioneuvosto.fi/en/ marin/government-programme/carbon-neutral-finland-that-protectsbiodiversity. Accessed 26 Nov 2020

7. Government of Denmark (2020) Lov om klima. https://www.retsinform ation.dk/eli/lta/2020/965. Accessed 8 Jan 2021.

8. Eurostat (2018) Eurostat Online Database. EU Commission http://ec europa.eu/eurostat/data/database. Accessed 1 Sep 2018

9. Hansen AC, Berlina A (2018) Bioenergy development in swedenframeworks for success. In: Leal Filho W, Pociovălișteanu DM, de Brito PR, de Lima I (eds) Towards a sustainable bioeconomy: principles, challenges and perspectives. Springer International Publishing, Cham, pp 457-481 (10.1007/978-3-319-73028-8_23)

10. Wetterstrand M (2019) Biojet för flyget. Norstedts Juridik, Stockholm

11. Bøeng AC, Halvorsen B, Larsen BM (2014) Kartlegging av oppvarmingsutstyr i husholdningene. Statistics Norway, Oslo

12. Statistics Finland (2016) Tilastokeskus - Statisticentralen. http://www. stat.fi/index.html. Accessed 14 Apr 2016

13. Norwegian Tax Administration (2016) Skatteetaten - Elektrisk kraft. Norwegian Tax Administration, Oslo

14. Swedish Tax Agency (2016) Skattesatser på bränslen och el under 2016. Swedish Tax Agency, Stockholm

15. EUROSTAT (2016) Eurostat Database. European Commission http://ec. europa.eu/eurostat/data/database. Accessed 14 Apr 2016

16. Intergovernmental Panel on Climate Change (2018) Global warming of $1.5^{\circ} \mathrm{C}$. Summary for policy-makers. http://report.ipcc.ch/sr15/pdf/sr15 spm_final.pdf. Accessed 31 May 2021

17. Signatories (2018) Letter from scientists to the eu parliament regarding forest biomass. https://empowerplants.files.wordpress.com/2018/01/ scientist-letter-on-eu-forest-biomass-796-signatories-as-of-january-162018.pdf. Accessed 30 Sep 2019

18. Schulze E-D, Körner C, Law BE, Haberl H, Luyssaert S (2012) Large-scale bioenergy from additional harvest of forest biomass is neither sustainable nor greenhouse gas neutral. GCB Bioenergy 4:611-616. https://doi. org/10.1111/j.1757-1707.2012.01169.x

19. Norton M, Baldi A, Buda V, Carli B, Cudlin P, Jones MB et al (2019) Serious mismatches continue between science and policy in forest bioenergy. GCB Bioenergy 11:1256-1263. https://doi.org/10.1111/gcbb.12643

20. World Commission on Environment and Development (1987) Report of the World Commission on Environment and Development: Our Common Future. https://sustainabledevelopment.un.org/content/docum ents/5987our-common-future.pdf. Accessed 2 Apr 2019.

21. United Nations (1993) Agenda 21: programme of action for sustainable development; Rio Declaration on Environment and Development; Statement of Forest Principles: the final text of agreements negotiated by governments at the United Nations Conference on Environment and Deve. United Nations Dept. of Public Information, New York.

22. United Nations (2015) Sustainable development goals. https://www. un.org/sustainabledevelopment/sustainable-development-goals/. Accessed 11 Jul 2018.

23. Intergovernmental Panel on Climate Change (2010) Guidance Note for Lead Authors of the IPCC Fifth Assessment Report on Consistent Treatment of Uncertainties. Intergovernmental Panel on Climate Change (IPCC) https://www.ipcc.ch/site/assets/uploads/2017/08/AR5_Uncer tainty_Guidance_Note.pdf. Accessed 28 Aug 2020.

24. Beck U (1992) Risk Society, towards a new modernity. Sage, London

25. Beck U (2005) Encyclopedia of social theory. In: Risk society. https://doi. org/10.4135/9781412952552.n244

26. Luhmann N (2014) Vertrauen: ein Mechanismus der Reduktion sozialer Komplexität, 5th edn. Lucius \& Lucius, Stuttgart

27. Renn O (2008) Risk Governance: Coping with Uncertainty in a Complex World. Earthscan, London

28. Kaplan JO, Krumhardt KM, Zimmermann N (2009) The prehistoric and preindustrial deforestation of Europe. Quat Sci Rev 28:3016-3034. https://doi.org/10.1016/j.quascirev.2009.09.028 
29. Grober U, Cunningham R (2012) Sustainability: a cultural history. Uit Cambridge, UK

30. Morin G-A, Kuusela K, Henderson-Howat DB, Efstathiadis NS, Oroszi S, Sipkens H (1996) Long-term historical changes in the forest resource. United Nations, Geneva

31. Fenchel T, Larsen G, Vestergaard P, Møller PF, Sand-Jensen K, editors (2006) Naturen i Danmark. https://naturenidanmark.lex.dk/taxonomy/ 4551. Accessed 11 Nov 2020.

32. Ekelund $\mathrm{H}$, Hamilton $\mathrm{G}$ (2001) Skogspolitisk historia. Skogsstyrelsen http://shop.skogsstyrelsen.se/shop/9098/art45/4646045-67b381-1695. pdf. Accessed 11 Nov 2020

33. Forest Europe (2018) Forest Europe. http://foresteurope.org/foresteuro pe/. Accessed 13 Jul 2018.

34. Alcamo J, Bennett EM, (Program) Millennium Ecosystem Assessment (2003) Ecosystems and human well-being: a framework for assessment. Island Press, Washington

35. de Groot RS, Wilson MA, Boumans RMJ (2002) A typology for the classification, description and valuation of ecosystem functions, goods and services. Ecol Econ 41:393-408

36. Fisher B, Turner RK, Morling P (2009) Defining and classifying ecosystem services for decision making. Ecol Econ 68:643-653

37. Intergovernmental Science-Policy Platform on Biodiversity and Ecosystem Services I (2016) The methodological assessment report on scenarios and models of biodiversity and ecosystem services. Zenodo. https://doi.org/10.5281/zenodo.3235428

38. Maes J, Teller A, Erhard M, Liquete C, Braat L, Berry P, et al. (2013) Mapping and assessment of ecosystems and their services. https://doi.org/ $10.2779 / 75203$

39. Intergovernmental Panel on Climate Change. (2014) Climate Change 2014: Synthesis Report. Contribution of Working Groups I, II and II to the Fifth Assessment Report of the Intergovernmental Panel on Climate Change [Core Writing Team, R.K. Pachauri and L.A. Meyer (eds.)]. Geneva: Intergovernmental Panel on Climate Change.

40. Lattimore B, Smith CT, Titus BD, Stupak I, Egnell G (2009) Environmental factors in woodfuel production: opportunities, risks, and criteria and indicators for sustainable practices. Biomass Bioenergy 33:1321-1342

41. European Commission (2014) State of play on the sustainability of solid and gaseous biomass used for electricity, heating and cooling in the EU. Commission staff working dokcument https://ec.europa.eu/energy/ sites/ener/files/2014_biomass_state_of_play_.pdf. Accessed $30 \mathrm{Sep}$ 2019.

42. European Commission (2016) Commission Staff Working Document: Impact Assessment - Sustainability of Bioenergy. https://ec.europa.eu/ energy/sites/ener/files/documents/1_en_impact_assessment_part4_ v4_418.pdf. Accessed 31 May 2021

43. European Parliament and Council of the European Union (2018) Directive (EU) 2018/ 2001 of the European Parliament and of the Council of the European Union—of 11 December 2018-on the promotion of the use of energy from renewable sources. https://eur-lex.europa.eu/legalcontent/EN/TXT/PDF/?uri=CELEX:32018L2001\&from=EN. Accessed 31 May 2021

44. Repstad P (1984) Fra ilden til asken: En studie i religiøs passivisering Universitetsforlaget, Stavanger

45. Signatories (2017) Public statement. http://www.bios.fi/publicstat ement/publicstatement240317.pdf. Accessed 6 Oct 2019

46. Fern (2019) How the European Union should step up action against deforestation. Position paper on the EU Commission decision on public consultation on stepping up EU action against Deforestation and forest degradation https://www.fern.org/fileadmin/uploads/fern/Documents/ Fern-submission-EU-consultation-deforestation.pdf. Accessed 6 Oct 2019

47. Fargione J, Hill J, Tilman D, Polasky S, Hawthorne P (2008) Land clearing and the biofuel carbon debt. Science. https://doi.org/10.1126/science. 1152747

48. Johnson D, Curtis P (2001) Effects of forest management on soil C and N storage: meta analysis. For Ecol Manag 140:227-227

49. Clarke N, Gundersen P, Jonsson-Belyazid U, Kjonaas O, Persson T, Sigurdsson B et al (2015) Influence of different tree-harvesting intensities on forest soil carbon stocks in boreal and northern temperate forest ecosystems. For Ecol Manag 351:9-19
50. Persson T, Egnell G (2018) Stump harvesting for bioenergy: a review of climatic and environmental impacts in northern Europe and America. WIREs Energy Environ 7:e307. https://doi.org/10.1002/wene.307

51. DCE (2019) Denmark's national inventory report 2019: emission inventories 1990-2017: submitted under the United Nations Framework Convention on Climate Change and the Kyoto Protocol. DCE - Nationalt Center for Miljø og Energi, Aarhus

52. Nielsen O-K, Plejdrup MS, Winther M, Nielsen M, Gyldenkærne S, Mikkelsen MH, Albrektsen R, Thomsen M, Hjelgaard K, Fauser P, Bruun HG, Johannsen VK, Nord-Larsen T, Vesterdal L, Callesen I, Caspersen $\mathrm{OH}$, Scott-Bentsen N, Rasmussen E, Petersen SB, Olsen TM, Hansen MG (2020) Denmark's National Inventory Report 2020. Emission Inventories 1990-2018-Submitted under the United Nations Framework Convention on Climate Change and the Kyoto Protocol. Aarhus University, DCE - Danish Centre for Environment and Energy, 900 pp. Scientific Report No. 372 http://dce2.au.dk/pub/SR372.pdf. Accessed 31 May 2021

53. Johannsen VK, Nord-Larsen T, Bentsen NS, Vesterdal L (2019): Danish National Forest Accounting Plan 2021-2030 - resubmission 2019. IGN report, December 2019. Department of Geosciences and Resource Management, University of Copenhagen, Frederiksberg. 112 pp. ill https://kefm.dk/media/7113/dnfap_revised_2019_web20 191219.pdf. Accessed 9 Dec 2020

54. United Nations (1992) United Nations Framework Convention on Climate Change. http://unfccc.int/resource/docs/convkp/conveng. pdf. Accessed 31 May 2021

55. United Nations (2016) The Paris Agreement. http://unfccc.int/docum entation/documents/advanced_search/items/3594.php?rec=j\& priref $=600008865$. Accessed 31 May 2021

56. European Parliament and Council of the European Union (2018) Regulation (EU) 2018/841 of the European Parliament and of the Council of the European Union of 30 May 2018 on the inclusion of greenhouse gas emissions and removals from land use, land use change and forestry in the 2030 climate and energy framework, and amending Regulation (EU) No 525/2013 and Decision No 529/2013/ EU (Text with EEA relevance). http://data.europa.eu/eli/reg/2018/ 841/oj/eng. Accessed 29 Dec 2020

57. Norwegian Ministry of Climate and Environment (2020) National forestry accounting plan for Norway for the first commitment period 2021-2025. NFAP https://www.regjeringen.no/contentassets/cd654 3b5e7f947cd9a086c3528adc654/norways-national-forestry-accou nting-plan_2021-2025.pdf. Accessed 16 Nov 2020

58. Swedish Ministry for the Environment and Energy (2019) National forestry accounting plan for Sweden. NFAP https://www.government. se/4a9f07/contentassets/730d6345a5d745b1 bc5f084e2f0offf7/revis ed-national-forestry-accounting-plan-for-sweden. Accessed $16 \mathrm{Nov}$ 2020

59. Finnish Ministry of Agriculture and Forestry, Natural Resources Institute Finland (2019) National Forestry Accounting plan for Finland. https://www.luke.fi/wp-content/uploads/2019/12/NFAP-for-Finland20-December-2019.pdf. Accessed 16 Nov 2020

60. Boulding KE (1966) The economics of the coming spaceship earth. In: Jarrett $\mathrm{H}$ (ed) Environmental quality in a growing economy. Johns Hopkins University Press, Baltimore

61. Sathre R, O'Connor J (2010) Meta-analysis of greenhouse gas displacement factors of wood product substitution. Environ Sci Policy 13:104-114. https://doi.org/10.1016/j.envsci.2009.12.005

62. Seppälä J, Heinonen T, Pukkala T, Kilpeläinen A, Mattila T, Myllyviita Tet al (2019) Effect of increased wood harvesting and utilization on required greenhouse gas displacement factors of wood-based products and fuels. J Environ Manage 247:580-587. https://doi.org/ 10.1016/j.jenvman.2019.06.031

63. Leskinen P, Cardellini G, González-García S, Hurmekoski E, Sathre R, Seppälä J et al (2018) Substitution effects of wood-based products in climate change mitigation. From science to policy. European Forest Institute, Joensuu (10.36333/fs07)

64. Nylund J-E (2009) Forestry legislation in Sweden. The Swedish University of Agricultural Sciences Department of Forest Products. https://pub.epsilon.slu.se/5503/1/Forestry_legislation_in_Sweden. pdf. Accessed 28 Oct 2019 
65. Landbruksdirektoratet (Norway) (1932) Lov om skogvern. https:// www.landbruksdirektoratet.no/no/eiendom-og-skog/skog-og-klima/ vernskog/regelverk/lov-om-skogvern. Accessed 30 Oct 201

66. Finnish Ministry of Agriculture and Forestry (1996) Skogslagen (The Forest Act). https://mmm.fi/sv/skogar/skogsbruk/hallbart-skogsbruk/ skogslag. Accessed 6 Feb 2021

67. Fritzbøger B (2009) Environmental Agency - Forest histories from Denmark, C. 1500-2000. In: Björk F, Eliasson P, Poulsen B (eds) Transcending boundaries: environmental histories from the Øresund region. Malmö

68. Madsen P, Jensen FA, Fodgaard S (2015) Afforestation in Denmark. In: Stanturf JA (ed) Restoration of boreal and temperate forests, 2nd edn. CRC Press Integrative studies in water management \& land development, Boca Raton, pp 201-216

69. Lindahl KB, Sténs A, Sandstrøm C, Johansson J, Lidskog R, Ranius T, Roberge JM (2017) The Swedish forestry model: More of everything? For Policy Econ 77:44-55. https://doi.org/10.1016/j.forpol.2015.10.012

70. European Parliament and Council of the European Union (2009) Fuel Quality Directive. Directive 2009/30/EC of the European Parliament and of the Council of 23 April 2009 amending Directive 98/70/EC as regards the specification of petrol, diesel and gas-oil and introducing a mechanism to monitor and reduce greenhouse gas emissions and amending Council Directive 1999/32/EC as regards the specification of fuel used by inland waterway vessels and repealing Directive 93/12/EEC. https:// eur-lex.europa.eu/legal-content/EN/TXT/?uri=celex\%3A32009L0030. Accessed 31 May 2021

71. Stupak I, Smith CT, Clarke N, al-Saedi T, Beniušienè L, Bentsen NS, Cheung Q, Dale V, van Dam J, Diaz-Chavez R, Fritsche U, Futter M, Gan J, Hakala K, Horschig T, Junginger M, Kitigawa Y, Kittler B, Kline K, Lalonde C, Larsen S, Lazdina D, Mai-Moulin TPT, Mansoor M, Mupondwa E, Nair S, Newlands N, Nichiforel L, Palviainen M, Stanturf J, Schaubach K, Perez Sierra JA, Tilvikiene V, Titus B, Thrän D, Ugarte S, Ukonmaanaho L, Varnagirytè-Kabašinskienè I, Wellisch M (2019) Approaches to creating trust in sustainability of bioenergy through effective governance: summary of findings under Objective 2 of the IEA Bioenergy inter-Task project "Measuring, governing and gaining support for sustainable bioenergy supply chains. IEA Bioenergy Report No. 03. University of Copenhagen, Copenhagen

72. European Parliament and Council of the European Union (2009) Directive 2009/28/EC of the European Parliament and of the Council of 23 April 2009 on the promotion of the use of energy from renewable sources and amending and subsequently repealing Directives 2001/77/ EC and 2003/30/EC. https://eur-lex.europa.eu/legal-content/EN/ALL/? uri $=$ celex\%3A32009L0028. Accessed 31 May 2021

73. European Parliament and Council of the European Union (2010) Regulation (EU) No 995/2010 of the European Parliament and of the Council of the European Union of 20 October 2010 laying down the obligations of operators who place timber and timber products on the market. https://eurlex.europa.eu/LexUriServ/LexUriServ.do?uri=OJ:L:2010:295: 0023:0034:EN:PDF. Accessed 31 May 2021

74. European Commission (2003) Communication from the Commission to the Council and the European Parliament-Forest Law Enforcement, Governance and Trade (FLEGT) — proposal for an EU Action Plan. https://eur-lex.europa.eu/legal-content/EN/TXT/PDF/?uri=CELEX: 52003DC0251\&from=EN. Accessed 5 Oct 2019

75. European Forest Institute (2020) Forest law enforcement, governance and trade. https://www.euflegt.efi.int/home. Accessed 19 Nov 2020

76. European Commission (2019) Communication on stepping up EU action to protect and restore the world's forests. https://ec.europa.eu/ info/files/communication-2019-stepping-eu-action-protect-and-resto re-worlds-forests_en. Accessed 29 Oct 2019.

77. Larsen S, Bentsen NS, Stupak I (2019) Implementation of voluntary verification of sustainability for solid biomass - a case study from Denmark. Energy Sustain Soc 9(1):33. https://doi.org/10.1186/s13705-019-0209-0

78. Government of Denmark (2020) Aftale_om bæredygtighedskrav til træbiomasse til energi.pdf. https://kefm.dk/Media/C/C/Aftale_om\% 20b\%C3\%A6redygtighedskrav\%20til\%20tr\%C3\%A6biomasse\%20til\% 20energi.pdf. Accessed 14 Nov 2020

79. Programme for the Endorsement of Forest Certification PEFC Standards and Guides. https://www.pefc.org/standards-implementation/stand ards-and-guides. Accessed 29 Oct 2019
80. Forest Stewardship Council (2017) FSC International. https://ic.fsc.org/ en. Accessed 31 May 2021

81. International Organization for Standardization (2015) Sustainability criteria for bioenergy. International Organization for Standardization, Committee PC 248 https://www.iso.org/obp/ui/\#iso:std:iso:13065:ed-1: v1:en. Accessed 31 May 2021

82. European Committee for Standardization (2012-2014) Sustainably produced biomass for energy applications. https://standards.cen.eu/ dyn/www/f?p=204:110:0...FSP_PROJECT,FSP_ORG_ID:32722,648007\& $C S=1 D 03 F 930728 B F 1 B C 55 B 479 A 4 D 2 A C 6 F 1 C 2$. Accessed 31 May 2021

83. Maesano M, Ottaviano M, Lidestav G, Lasserre B, Matteucci G, Mugnozza GS, Marchetti M (2018) Forest certification map of Europe. iForest Biogeosci Forest 11:526-533. https://doi.org/10.3832/ifor2668-011

84. Sustainable Biomass Program (2020) What is the sustainable biomass program? https://sbp-cert.org/. Accessed 18 Apr 2020.

85. Forest Stewardship Council-United States (2020) FSC US Controlled Wood National Risk Assessment (US NRA). FSC United States https:// us.fsc.org:443/en-us/certification/controlled-wood/fsc-us-controlledwood-national-risk-assessment-us-nra. Accessed 19 Apr 2020.

86. Council of the European Union (2005) Council Regulation (EC) No 2173/2005 of 20 December 2005 on the establishment of a FLEGT licensing scheme for imports of timber into the European Community. https://eur-lex.europa.eu/legal-content/EN/TXT/?lang1=EN\&lang2= choose\&lang3=choose\&uri=CELEX\%3A02005R2173-20200101. Accessed 14 Aug 2020.

87. Preferred by Nature (2020) https:// https://preferredbynature.org/. Accessed 26 Feb 2021.

88. IRENA (2020) Renewable power generation costs in 2019. https://www. irena.org/publications/2020/Jun/Renewable-Power-Costs-in-2019. Accessed 9 Oct 2020.

89. Swedish Energy Agency and The Norwegian Water Resources and Energy Directorate (2020) The Swedish-Norwegian Electricity Certificate Market. Annual report. http://publikasjoner.nve.no/diverse/2020/elser tifikat2020engelsk.pdf. Accessed 30 Nov 2020.

90. Danish Energy Agency (2019) Faktaark om afgørelse af det teknologineutrale udbud 2018. Faktaark. Danish Energy Agency https://ens.dk/ service/aktuelle-udbud/teknologineutrale-udbud-2018-2019. Accessed 13 Jul 2019.

91. Danish Energy Agency (2020) Faktaark om afgørelse af det teknologineutrale udbud 2019. Technology neutral tenders https://ens.dk/sites/ ens.dk/files/Vindenergi/4a._faktaark___afgoerelse_af_teknologineutra It_udbud_2019_002.pdf. Accessed 1 Dec 2020.

92. Danish Ministry of Climate and Energy (2018) Energiaftale af 29. juni 2018. https://kefm.dk/media/6646/energiaftale2018.pdf. Accessed 18 Nov 2020.

93. Danish Ministry of Climate and Energy (2018) Lov om ændring af lov om fremme af vedvarende energi og lov om elforsyning. https://www. retsinformation.dk/Forms/R0710.aspx?id=205657. Accessed 4 Nov 2019.

94. Danish Energy Agency (2020) Biomasseanalyse. https://ens.dk/sites/ ens.dk/files/Bioenergi/biomasseanalyse_final_ren.pdf. Accessed 1 Dec 2020.

95. Finnish Energy Agency (2019) Support for seven projects awarded through auction. https://energiavirasto.fi/en/-/uusiutuvan-energiantarjouskilpailusta-tukea-seitsemalle-hankkeelle-hyvaksyttyjen-tarjo usten-keskihinta-2-5-euroa-mwh. Accessed 18 Nov 2020.

96. International Renewable Energy Agency (2019) Innovation landscape for a renewable-powered future. https://www.irena.org/publicatio ns/2019/Feb/Innovation-landscape-for-a-renewable-powered-future. Accessed 5 Feb 2021

97. European Commission (2014) Guidelines on State aid for environmenta protection and energy 2014-2020. https://eur-lex.europa.eu/legalconte nt/EN/TXT/?uri=CELEX\%3A52014XC0628\%2801\%29. Accessed 31 May 2021

98. European Commission (2021) Sustainable finance taxonomy-Regulation (EU) 2020/852. https://ec.europa.eu/info/law/sustainable-finan ce-taxonomy-regulation-eu-2020-852_en. Accessed 1 Jan 2021.

99. Natural Resources Institute Finland (LUKE) (2019) Statistics Database. Tilastotietokanta http://statdb.luke.f/PXWeb/pxweb/en/LUKE/LUKE_ 04\%20Metsa_02\%20Rakenne\%20ja\%20tuotanto_10\%20Hakkuuke 
rtyma\%20ja\%20puuston\%20poistuma/?tablelist=true\&rxid=157ac a12-585d-4d9c-84bd-13064cd00523. Accessed 28 Oct 2019.

100. Brännlund R, Söderholm P, Lundmark R (2010) Kampen om skogen koka, såga, bränna eller bevara? SNS Förlag, Stockholm

101. International Energy Agency (2021) Finland tender-based feed-in premium scheme for renewable power generation (30.12.2010/1396). Online policy database https://www.iea.org/policies/6539-finlandtender-based-feed-in-premium-scheme-for-renewable-power-gener ation-301220101396. Accessed 29 Jan 2021.

102. Swedish Ministry of Agriculture (1992) Biobränsle för framtiden slutbetänkanden av biobränslekommissionen. Swedish Ministry of Agriculture, Stockholm

103. Vero Skatt (2021) Punktskatt på elström och vissa bränslen. https:// www.vero.fi/sv/foretag-och-samfund/om-foretagsbeskattningen/punkt beskattning/elstrom_och_vissa_branslen/. Accessed 29 Jan 2021.

104. European Commission (2020) Quarterly Report on European Electricity Markets—-with special focus on extra-EU electricity trade. Market Observatory for Energy, DG Energy https://ec.europa.eu/energy/sites/ ener/files/documents/quarterly_report_on_european_electricity_ markets_q_2 2020.pdf. Accessed 3 Dec 2020.

105. Government of Denmark (2020) Denmark's Integrated National Energy and Climate Plan. https://ec.europa.eu/energy/sites/ener/files/docum ents/dk_final_necp_main_en.pdf. Accessed 5 Dec 2020.

106. Government of Sweden (2019) Sweden's Integrated National Energy and Climate Plan. https://ec.europa.eu/energy/sites/ener/files/docum ents/se_final_necp_main_en.pdf. Accessed 5 Dec 2020.

107. Government of Finland (2019) Finland's integrated energy and climate plan. https://ec.europa.eu/energy/sites/ener/files/documents/fi_final_ necp_main_en.pdf. Accessed 31 May 2021

108. Svenska Kraftnät (2019) Långsigtig marknadsanalys 2019. Långsiktsscenarier för elsystemets utveckling fram till år 2040. https://www.svk.se/ siteassets/om-oss/rapporter/2019/langsiktig-marknadsanalys-2018.pdf. Accessed 5 Dec 2020

109. Danish Energy Association (2019) VE Outlook 2019. Perspektiver for den vedvarende energi mod 2035. Dansk Energi https://www.danskenergi. dk/sites/danskenergi.dk/files/media/dokumenter/2019-02/NE_Outlo ok_2019_0.pdf. Accessed 4 Dec 2020.

110. Beck U (2003) What is globalization? Polity Press, Cambridge

111. Bauman Z (1998) On glocalization: or globalization for some, localization for others. Thesis Eleven 54:37-49

112. Robertson R (1995) 'Glocalization: Time-Space and HomogeneityHeterogeneity. In: Featherstone M, Lash M, Robertson R (eds) Global Modernities. Sage Publications, London, pp 25-44

113. Albrecht M (2014) Enlightenment in Norway's Oil-Shadow? Governance Assemblages of a Wood-based District Heating Network in Norway's Inland Region. J Environ Policy Plan. https://doi.org/10.1080/1523908X. 2014.964851

114. Giddens A (1991) The Consequences of Modernity. Polity Press, Cambridge

115. Eurostat (2020) Eurostat online database. Table nrg_bal_c. European Commission. https://ec.europa.eu/eurostat/data/database. Accessed 9 Apr 2020

116. Eurostat (2017) Eurostat online database. Table nrg_110a. European Commission. http://ec.europa.eu/eurostat/data/database. Accessed 19 Feb 2017.

117. Natural Resources Institute Finland (2020) Tilastotietokanta-Statistics Database. Luke_Met_Mvarat_1.24 http://statdb.luke.fi/PXWeb/pxweb/ en/LUKE/LUKE_04\%20Metsa_06\%20Metsavarat/?rxid=f8ed5f389607-4c55-91c9-791d660b234e. Accessed 25 Dec 2020.
118. Statistics Norway (2020) Statistikkbanken. https://www.ssb.no/statb ank/list/skogav/. Accessed 25 Dec 2020.

119. Statistics Denmark (2020) Statistikbanken. SKOVRG01 https://www.stati stikbanken.dk/statbank5a/default.asp?w=1440. Accessed 25 Dec 2020.

120. Swedish University of Agricultural Sciences (2020) Riksskogstaxeringen. RT53 https://skogsstatistik.slu.se/pxweb/sv/OffStat/OffStat_ProduktivS kogsmark_Tillvaxt/PS_Tillvaxt_avverkning_fig.px/. Accessed 25 Dec 2020.

121. Statistics Norway (2019) Statistikkbanken. ssb.no https://www.ssb.no/ statbank. Accessed 6 Oct 2019.

122. Statistics Sweden (2019) Statistikbanken. http://www.scb.se/hitta-stati stik/sok/. Accessed 29 Sep 2019

123. Swedish Forest Agency (2019) Skogsstyrelsens statistikdatabas. http:// pxweb.skogsstyrelsen.se/pxweb/sv/Skogsstyrelsens\%20statistikdata bas/?rxid=03eb67a3-87d7-486d-acce-92fc8082735d. Accessed 30 Sep 2019.

124. Eurostat (2019) Eurostat online database. Table lan_Icv_ovw. European Commission. https://ec.europa.eu/eurostat/data/database. Accessed 19 Oct 2019.

125. Eurostat (2019) Eurostat online database. Table for_sup_cp. European Commission. https://ec.europa.eu/eurostat/data/database. Accessed 29 Oct 2019.

126. Statistics Norway (1960) Skogbrukstellingen i Norge 1. September 1957 1:439. Statistics Norway, Oslo

127. Statistics Norway (1995) Statistisk årbok 1995. Statistics Norway, Oslo

128. Norwegian Institute of Bioeconomy Research (2020) Norway's National Forest Inventory. https://landsskog.nibio.no/. Accessed 11 Dec 2020

129. UNFCCC (2019) Greenhouse Gas Inventory Data. Flexible queries Annex I countries https://di.unfccc.int/flex_annex1. Accessed 28 Sep 2019

130. Claesson S, Duvemo K, Wikberg P, Lundström A (2015) Skogliga konsekvensanalyser 2015 - SKA 15. Rapport 10-2015. Skogsstyrelsen, Jönköping

131. Lundblad M (2019) Scenarier för den svenska skogen och skogsmarkens utsläpp och upptag av växthusgaser. https://www.slu.se/globalasse ts/ew/org/inst/mom/ma/klimatrapportering/ru_lulucf_prognoser_ vaxthusgaser_skog_skogsmark_slutrapport.pdf. Accessed 7 Oct 2019

132. Norwegian Institute of Bioeconomy Research (2018) Alternative referansebaner for forvaltet skog. https://www.skog.no/wp-content/uploa ds/2018/12/Alternative-referansebaner-for-forvaltet-skog-NIBIO-OGMilj\%C3\%B8direktoratet.pdf. Accessed 7 Oct 2019

133. Koljonen T, Soimakallio S, Lehtilä A, Honkatukia J, Hildén M, Rehunen A, et al. (2019) Pitkän aikavälin kokonaispäästökehitys. TT Technical Research Centre of Finland Ltd and the Finnish Environment Institute SYKE https://julkaisut.valtioneuvosto.fi/bitstream/handle/10024/ 161409/24-2019-Pitkan\%20aikavalin\%20kokonaispaastokehitys.pdf? sequence $=1$ \&isAllowed $=\mathrm{y}$.Accessed 7 Oct 2019

134. Natural Resources Institute Finland (2018) Statistics database. http:// statdb.luke.fi/PXWeb/pxweb/en/LUKE/LUKE_04\%20Metsa_04\%20Tal ous_02\%20Teollisuuspuun\%20kauppa_02\%20Kuukausitilastot/? rxid=001 bc7da-70f4-47c4-a6c2-c9100d8b50db. Accessed 1 Sep 2018

135. Landbruksdirektoratet (Norway) (2017) Tømmeravvirkning. https:// www.landbruksdirektoratet.no/no/statistikk/skogbruk/tommeravvi rkning\#grunndata. Accessed 1 Sep 2018d

\section{Publisher's Note}

Springer Nature remains neutral with regard to jurisdictional claims in published maps and institutional affiliations. 